\title{
Genetics and the heart rate response to exercise
}

\author{
Yordi J. van de Vegte ${ }^{1} \cdot$ Balewgizie S. Tegegne ${ }^{3} \cdot$ Niek Verweij $^{1} \cdot$ Harold Snieder $^{3} \cdot$ Pim van der Harst ${ }^{1,2,4}$
}

Received: 11 October 2018 / Accepted: 18 March 2019 / Published online: 27 March 2019

(c) The Author(s) 2019

\begin{abstract}
The acute heart rate response to exercise, i.e., heart rate increase during and heart rate recovery after exercise, has often been associated with all-cause and cardiovascular mortality. The long-term response of heart rate to exercise results in favourable changes in chronotropic function, including decreased resting and submaximal heart rate as well as increased heart rate recovery. Both the acute and long-term heart rate response to exercise have been shown to be heritable. Advances in genetic analysis enable researchers to investigate this hereditary component to gain insights in possible molecular mechanisms underlying interindividual differences in the heart rate response to exercise. In this review, we comprehensively searched candidate gene, linkage, and genome-wide association studies that investigated the heart rate response to exercise. A total of ten genes were associated with the acute heart rate response to exercise in candidate gene studies. Only one gene (CHRM2), related to heart rate recovery, was replicated in recent genome-wide association studies (GWASs). Additional 17 candidate causal genes were identified for heart rate increase and 26 for heart rate recovery in these GWASs. Nine of these genes were associated with both acute increase and recovery of the heart rate during exercise. These genes can be broadly categorized into four categories: (1) development of the nervous system (CCDC141, PAX2, SOX5, and CAV2); (2) prolongation of neuronal life span (SYT10); (3) cardiac development (RNF220 and MCTP2); (4) cardiac rhythm (SCN1OA and RGS6). Additional 10 genes were linked to long-term modification of the heart rate response to exercise, nine with heart rate increase and one with heart rate recovery. Follow-up will be essential to get functional insights in how candidate causal genes affect the heart rate response to exercise. Future work will be required to translate these findings to preventive and therapeutic applications.
\end{abstract}

Keywords Heart rate increase $\cdot$ Heart rate recovery $\cdot$ Exercise $\cdot$ Genetics

Yordi J. van de Vegte and Balewgizie S. Tegegne have contributed equally to this work.

Electronic supplementary material The online version of this article (https://doi.org/10.1007/s00018-019-03079-4) contains supplementary material, which is available to authorized users.

Pim van der Harst

p.van.der.harst@umcg.nl

1 Department of Cardiology, University of Groningen, University Medical Center Groningen, Hanzeplein 1, 9700 RB Groningen, The Netherlands

2 Department of Genetics, University of Groningen, University Medical Center Groningen, 9700 RB Groningen, The Netherlands

3 Department of Epidemiology, University of Groningen, University Medical Center Groningen, 9700 RB Groningen, The Netherlands

4 Durrer Center for Cardiogenetic Research, Netherlands Heart Institute, 3511 GC Utrecht, The Netherlands

\section{Introduction}

The regulation of resting heart rate is complex; autonomic tone, central and peripheral reflexes, hormonal influences, and factors intrinsic to the heart are all important determinants $[1,2]$. Despite recent developments in the understanding of the complex interplay of the plethora of biological mechanisms influencing resting heart rate [3], our understanding is still incomplete.

The acute heart rate response to exercise, heart rate increase during and heart rate recovery after exercise, offers unique insights into cardiac physiology compared to heart rate in rest and can therefore be exploited to obtain additional information on cardiac function [4]. Impaired increase of heart rate during exercise (chronotropic incompetence) and an attenuated heart rate recovery have been associated with all-cause mortality and sudden cardiac death in healthy individuals [5-7] and in those with cardiac disease, including individuals with heart failure [8] and coronary artery 
disease [9]. Regular endurance exercise training has been proven to shift the cardiac autonomic balance towards vagal dominance [10]. The long-term response of heart rate to exercise results in favourable changes in chronotropic function, including decreased resting and submaximal heart rate as well as increased heart rate recovery [11].

Both the acute and long-term responses of heart rate to exercise have been shown to have a large heritable component [12-17]. Development in the understanding of the human genome and genetic analysis enables researchers to investigate the possible molecular mechanisms underlying interindividual differences in the acute and long-term heart rate response to exercise [18]. In this review, we summarize the current knowledge of the acute and long-term heart rate response to exercise, with a focus on the genetic contribution. In addition, we identify gaps in our knowledge and discuss possible future directions that might be of interest to enhance the understanding of the heart rate response to exercise and consider its potential clinical applications.

\section{Acute response}

\section{Heart rate increase}

In general, the regulation of the circulatory system during exercise involves several adaptations. These adaptations include dilatation of resistance vessels in the active muscles, a decrease in vagal outflow to the heart, followed by an increase of sympathetic outflow. If exercise is intense, the cholinergic fibers to the adrenal medulla are also activated, resulting in release of epinephrine into the circulation [19]. Under normal physiological conditions, this results in increased venous return, contractility, and heart rate [20]. In turn, ejection fraction increases due to a greater ejection of blood at the end of systole and increased diastolic filling of the ventricles as the duration of the systole decreases with increased heart rate [20].

The increase of heart rate during exercise is for a major part attributable to the decrease in vagal tone followed by an increase in sympathetic outflow and an increase in levels of circulating catecholamines [19]. It has been shown that a substantial component of interindividual differences in the heart rate increase during exercise is genetically determined, with heritability estimates ranging from 0.17 to 0.32 (Table 1) [12, 14, 15]. This suggests that genetic analyses may identify novel biological mechanisms involved in the regulation of heart rate response to exercise.

Several studies have focussed on identifying genetic determinants that explain interindividual differences in heart rate increase during exercise. Genes investigated in these studies are summarized in Table 2, shown in Fig. 1, and are further discussed here. The ACE gene was one of the first candidate genes thoroughly investigated for its possible relationship with the heart rate response to exercise [21]. Genetic association studies focusing on the effect of the $A C E$ gene on heart rate increase during exercise reported many conflicting results [12, 22-25]. Some studies tested genes for their indirect effect on the sympathetic nervous system. One study observed that the NOS3 gene,

Table 1 Heritability estimates for the acute and long-term effect of exercise on heart rate response

\begin{tabular}{|c|c|c|c|c|c|}
\hline Heritability type & Heritability & Type of exercise & Population & $N$ & Author, year \\
\hline \multicolumn{6}{|c|}{ Acute response: heart rate increase } \\
\hline Family & 0.32 & Submaximal treadmill test & General population & 2053 & Ingelsson et al. (2007) [12] \\
\hline SNP-based & 0.22 & Submaximal bicycle & General population & 58,818 & Verweij et al. (2018) [14] \\
\hline SNP-based & 0.17 & Submaximal bicycle & General population & 66,800 & Ramirez J et al. (2018) [15] \\
\hline \multicolumn{6}{|c|}{ Acute response: heart rate recovery } \\
\hline Family $^{\mathrm{a}}$ & 0.34 & Submaximal treadmill test & General population & 2053 & Ingelsson et al. (2007) [12] \\
\hline Twins and sibling ${ }^{\mathrm{b}}$ & 0.60 and 0.65 & Maximal bicycle & General population & 491 & Nederend et al. (2016) [13] \\
\hline SNP-based ${ }^{\mathrm{c}}$ & 0.22 & Submaximal bicycle & General population & 58,818 & Verweij et al. (2018) [14] \\
\hline SNP-based $^{c}$ & 0.12 & Submaximal bicycle & General population & 66,665 & Ramirez et al. (2018) [15] \\
\hline \multicolumn{6}{|c|}{ Trainings response: heart rate increase } \\
\hline Family $^{\mathrm{d}}$ & 0.34 & Submaximal bicycle & General population & 481 & An et al. (2003) [17] \\
\hline Family $^{\mathrm{d}}$ & 0.36 & Submaximal bicycle & $\begin{array}{l}\text { Participants with high } \\
\text { blood pressure }\end{array}$ & 529 & Rice et al. (2002) [16] \\
\hline
\end{tabular}

Heritability estimates for the acute and long-term effect of exercise on heart rate response

${ }^{\mathrm{a}}$ Heart rate recovery measured after $180 \mathrm{~s}$

${ }^{\mathrm{b}}$ Heart rate recovery measured after, respectively, 60 and $180 \mathrm{~s}$

${ }^{\mathrm{c}}$ Heart rate recovery measured after $60 \mathrm{~s}$

${ }^{d} 20$ weeks during endurance training program at submaximal $(50 \mathrm{~W})$ levels 
Table 2 Summary of genes involved in acute heart rate increase

\begin{tabular}{|c|c|c|c|c|c|c|c|c|c|}
\hline Gene & Variant & $\begin{array}{l}\text { Chromosome/ } \\
\text { position }\end{array}$ & $\begin{array}{l}\text { Minor/ } \\
\text { major allele/ } \\
\text { MAF }\end{array}$ & $\begin{array}{l}\text { Type of } \\
\text { study }\end{array}$ & $\begin{array}{l}\text { Increase/ } \\
\text { decrease }\end{array}$ & $P$ value & $\begin{array}{l}\text { Type of } \\
\text { exercise test }\end{array}$ & Population & Author; year \\
\hline$A C E^{\mathrm{a}}$ & $\begin{array}{l}\text { Del intron } \\
16\end{array}$ & $17: 63488529$ & $\begin{array}{l}\text { Deletion/ } \\
\text { insertion }\end{array}$ & Candidate & - & $>5.00 \times 10^{-2}$ & $\begin{array}{l}\text { Maximal } \\
\text { and sub- } \\
\text { maximal } \\
\text { bicycle }\end{array}$ & General & $\begin{array}{l}\text { Rankinen } \\
\text { et al. (2000) } \\
\text { [25] }\end{array}$ \\
\hline$A D R A 1 A$ & rs544215 & $8: 26712028$ & $\mathrm{C} / \mathrm{T} / 0.46$ & Candidate & $\downarrow$ & $5.00 \times 10^{-3}$ & $\begin{array}{l}\text { Standard } \\
\text { Bruce }\end{array}$ & General & $\begin{array}{l}\text { Ingelsson } \\
\text { et al. (2007) } \\
\text { [12] }\end{array}$ \\
\hline$A D R A 1 D$ & rs 3787441 & $20: 4205059$ & G/A/0.27 & Candidate & $\downarrow$ & $7.00 \times 10^{-3}$ & $\begin{array}{c}\text { Standard } \\
\text { Bruce }\end{array}$ & General & $\begin{array}{l}\text { Ingelsson } \\
\text { et al. (2007) } \\
\text { [12] }\end{array}$ \\
\hline$A D R B 1$ & rs 1801253 & $10: 114045297$ & $\mathrm{C} / \mathrm{G} / 0.28$ & Candidate & $\downarrow$ & $<5.00 \times 10^{-2}$ & Maximal & $\begin{array}{l}\text { Patients in } \\
\text { cardiac } \\
\text { rehab }\end{array}$ & $\begin{array}{l}\text { Defoor et al. } \\
\text { (2005) [29] }\end{array}$ \\
\hline$A D R B 1$ & rs1801252 & $10: 114044277$ & $\mathrm{G} / \mathrm{A} / 0.21$ & Candidate & $\downarrow$ & $<5.00 \times 10^{-2}$ & Maximal & $\begin{array}{l}\text { Patients in } \\
\text { cardiac } \\
\text { rehab }\end{array}$ & $\begin{array}{l}\text { Defoor et al. } \\
(2005) \text { [29] }\end{array}$ \\
\hline$A D R B 2$ & rs 1042713 & $5: 148826877$ & A/G/- & Candidate & $\downarrow$ & $<5.00 \times 10^{-2}$ & $\begin{array}{l}\text { Hand grip } \\
\text { test }\end{array}$ & General & $\begin{array}{l}\text { Eisenach } \\
\text { et al.(2003) } \\
{[30]}\end{array}$ \\
\hline$C A V 2$ & rs28495552 & $7: 116113744$ & $\mathrm{C} / \mathrm{G} / 0.50$ & GWAS & $\downarrow$ & $2.80 \times 10^{-11}$ & $\begin{array}{l}\text { Sub- } \\
\text { maximal } \\
\text { bicycle }\end{array}$ & General & $\begin{array}{r}\text { Ramirez et al. } \\
\text { (2018) [15] }\end{array}$ \\
\hline$C C D C 141$ & rs10497529 & $2: 179839888$ & A/G/0.04 & GWAS & $\uparrow$ & $2.50 \times 10^{-9}$ & $\begin{array}{l}\text { Sub- } \\
\text { maximal } \\
\text { bicycle }\end{array}$ & General & $\begin{array}{l}\text { Ramirez et al. } \\
(2018) \text { [15] }\end{array}$ \\
\hline$G N A S 1^{\mathrm{b}}$ & rs7121 & $20: 58903752$ & $\mathrm{C} / \mathrm{T} / 0.37$ & Candidate & $\uparrow$ & $<5.00 \times 10^{-2}$ & Ergometer & $\begin{array}{l}\text { Referred for } \\
\text { exercise } \\
\text { test }\end{array}$ & $\begin{array}{l}\text { Nieminen } \\
\text { et al. (2006) } \\
\text { [28] }\end{array}$ \\
\hline$H M G A 2$ & rs 1480470 & $12: 66412130$ & $\mathrm{~A} / \mathrm{G} / 0.37$ & GWAS & $\uparrow$ & $3.40 \times 10^{-08}$ & $\begin{array}{l}\text { Sub- } \\
\text { maximal } \\
\text { bicycle }\end{array}$ & General & $\begin{array}{l}\text { Ramirez et al. } \\
\text { (2018) [15] }\end{array}$ \\
\hline МСТP2 & rs 12906962 & $15: 95312071$ & $\mathrm{C} / \mathrm{T} / 0.32$ & GWAS & $\downarrow$ & $3.50 \times 10^{-13}$ & $\begin{array}{l}\text { Sub- } \\
\text { maximal } \\
\text { bicycle }\end{array}$ & General & $\begin{array}{l}\text { Ramirez et al. } \\
\text { (2018) [15] }\end{array}$ \\
\hline$M C T P 2$ & rs 12906962 & $15: 95312071$ & $\mathrm{C} / \mathrm{T} / 0.33$ & GWAS & $\downarrow$ & $2.70 \times 10^{-14}$ & $\begin{array}{l}\text { Sub- } \\
\text { maximal } \\
\text { bicycle }\end{array}$ & General & $\begin{array}{l}\text { Verweij et al. } \\
\text { (2018) [14] }\end{array}$ \\
\hline$N O L A^{\mathrm{c}, \mathrm{d}}$ & rs6847149 & $4: 111157701$ & - & GWAS & - & $2.74 \times 10^{-06}$ & $\begin{array}{l}\text { Standard } \\
\text { Bruce }\end{array}$ & General & $\begin{array}{l}\text { Vasan et al. } \\
\text { (2007) [34] }\end{array}$ \\
\hline$N O S 3^{\mathrm{e}}$ & rs1799983 & $7: 150999023$ & $\mathrm{~T} / \mathrm{G} / 0.26$ & Candidate & $\downarrow$ & $4.00 \times 10^{-2}$ & $\begin{array}{r}\text { Naughton } \\
\text { protocol }\end{array}$ & $\begin{array}{c}\text { Post-men- } \\
\text { opausal } \\
\text { women }\end{array}$ & $\begin{array}{l}\text { Hand et al. } \\
\text { (2006) [26] }\end{array}$ \\
\hline$P A X 2$ & rs11190709 & $10: 102552663$ & $\mathrm{G} / \mathrm{A} / 0.12$ & GWAS & $\uparrow$ & $1.30 \times 10^{-11}$ & $\begin{array}{l}\text { Sub- } \\
\text { maximal } \\
\text { bicycle }\end{array}$ & General & $\begin{array}{r}\text { Ramirez et al. } \\
\text { (2018) [15] }\end{array}$ \\
\hline POP4 & rs 12986417 & $19: 30109533$ & $\mathrm{~A} / \mathrm{G} / 0.35$ & GWAS & $\downarrow$ & $1.00 \times 10^{-9}$ & $\begin{array}{l}\text { Sub- } \\
\text { maximal } \\
\text { bicycle }\end{array}$ & General & $\begin{array}{l}\text { Verweij et al. } \\
\text { (2018) [14] }\end{array}$ \\
\hline POP4 & rs 7255293 & 19:30104198 & $\mathrm{G} / \mathrm{A} / 0.42$ & GWAS & $\downarrow$ & $3.20 \times 10^{-9}$ & $\begin{array}{l}\text { Sub- } \\
\text { maximal } \\
\text { bicycle }\end{array}$ & General & $\begin{array}{c}\text { Ramirez et al. } \\
\quad(2018)[15]\end{array}$ \\
\hline PPIL1 & rs 236352 & $6: 36817113$ & A/G/0.34 & GWAS & $\uparrow$ & $6.40 \times 10^{-10}$ & $\begin{array}{l}\text { Sub- } \\
\text { maximal } \\
\text { bicycle }\end{array}$ & General & $\begin{array}{l}\text { Ramirez et al. } \\
\text { (2018) [15] }\end{array}$ \\
\hline
\end{tabular}


Table 2 (continued)

\begin{tabular}{|c|c|c|c|c|c|c|c|c|c|}
\hline Gene & Variant & $\begin{array}{l}\text { Chromosome/ } \\
\text { position }\end{array}$ & $\begin{array}{l}\text { Minor/ } \\
\text { major allele/ } \\
\text { MAF }\end{array}$ & $\begin{array}{l}\text { Type of } \\
\text { study }\end{array}$ & $\begin{array}{l}\text { Increase/ } \\
\text { decrease }\end{array}$ & $P$ value & $\begin{array}{l}\text { Type of } \\
\text { exercise test }\end{array}$ & Population & Author; year \\
\hline$R G S 6$ & rs 17180489 & $14: 72885471$ & $\mathrm{C} / \mathrm{G} / 0.14$ & GWAS & $\uparrow$ & $2.50 \times 10^{-11}$ & $\begin{array}{l}\text { Sub- } \\
\text { maximal } \\
\text { bicycle }\end{array}$ & General & $\begin{array}{l}\text { Verweij et al. } \\
\text { (2018) [14] }\end{array}$ \\
\hline$R N F 220$ & rs 272564 & $1: 45012273$ & C/A/0.28 & GWAS & $\downarrow$ & $7.40 \times 10^{-12}$ & $\begin{array}{l}\text { Sub- } \\
\text { maximal } \\
\text { bicycle }\end{array}$ & General & $\begin{array}{c}\text { Ramirez et al. } \\
\text { (2018) [15] }\end{array}$ \\
\hline$R P 1 L 1$ & rs58065122 & $8: 10526186$ & $\mathrm{~A} / \mathrm{G} / 0.42$ & GWAS & $\uparrow$ & $3.90 \times 10^{-10}$ & $\begin{array}{l}\text { Sub- } \\
\text { maximal } \\
\text { bicycle }\end{array}$ & General & $\begin{array}{c}\text { Ramirez et al. } \\
(2018) \text { [15] }\end{array}$ \\
\hline$R Y R 2^{\mathrm{c}, \mathrm{d}}$ & rs2819770 & $1: 234237045$ & - & GWAS & - & $3.53 \times 10^{-6}$ & $\begin{array}{l}\text { Standard } \\
\text { Bruce }\end{array}$ & General & $\begin{array}{l}\text { Vasan et al. } \\
\text { (2007) [34] }\end{array}$ \\
\hline SCN1OA & rs7433723 & $3: 38784957$ & G/A/0.42 & GWAS & $\downarrow$ & $4.50 \times 10^{-8}$ & $\begin{array}{l}\text { Sub- } \\
\text { maximal } \\
\text { bicycle }\end{array}$ & General & $\begin{array}{c}\text { Ramirez et al. } \\
\text { (2018) [15] }\end{array}$ \\
\hline SNCAIP & rs4836027 & $5: 121866990$ & $\mathrm{C} / \mathrm{T} / 0.32$ & GWAS & $\downarrow$ & $1.70 \times 10^{-15}$ & $\begin{array}{l}\text { Sub- } \\
\text { maximal } \\
\text { bicycle }\end{array}$ & General & $\begin{array}{r}\text { Verweij et al. } \\
\text { (2018) [14] }\end{array}$ \\
\hline SNCAIP & rs 4836027 & $5: 121866990$ & $\mathrm{C} / \mathrm{T} / 0.31$ & GWAS & $\downarrow$ & $9.90 \times 10^{-21}$ & $\begin{array}{l}\text { Sub- } \\
\text { maximal } \\
\text { bicycle }\end{array}$ & General & $\begin{array}{c}\text { Ramirez et al. } \\
\text { (2018) [15] }\end{array}$ \\
\hline SOX5 & rs4246224 & $12: 24784139$ & $\mathrm{~A} / \mathrm{G} / 0.15$ & GWAS & $\uparrow$ & $1.80 \times 10^{-14}$ & $\begin{array}{l}\text { Sub- } \\
\text { maximal } \\
\text { bicycle }\end{array}$ & General & $\begin{array}{r}\text { Ramirez et al. } \\
\text { (2018) [15] }\end{array}$ \\
\hline SYT10 & rs1343676 & $12: 33537387$ & $\mathrm{~T} / \mathrm{C} / 0.51$ & GWAS & $\downarrow$ & $1.50 \times 10^{-11}$ & $\begin{array}{l}\text { Sub- } \\
\text { maximal } \\
\text { bicycle }\end{array}$ & General & $\begin{array}{c}\text { Ramirez et al. } \\
\text { (2018) [15] }\end{array}$ \\
\hline$T C F 4$ & rs1125313 & 18:52859261 & C/A/0.50 & GWAS & $\uparrow$ & $3.90 \times 10^{-9}$ & $\begin{array}{l}\text { Sub- } \\
\text { maximal } \\
\text { bicycle }\end{array}$ & General & $\begin{array}{l}\text { Ramirez et al. } \\
\text { (2018) [15] }\end{array}$ \\
\hline
\end{tabular}

Genes found to be associated with heart rate increase during exercise are shown in alphabetical order and are then ordered on the year published. Variation stands for either an SNP or deletion/insertion mutation. MAF stands for Minor Allele Frequency. Effects of a variant (in- or decrease) on heart rate increase during exercise are shown for the Minor Allele. Candidate stands for candidate gene study. GWAS stands for genome-wide association study. A hyphen is shown in case information which was not reported

${ }^{a}$ Results from only one candidate gene study on ACE are shown; largest study was chosen; G allele in case of deletion; in case of insertion ATA CAGTCACTTTTTTTTTTTTTTTGAGACGGAGTCTCGCTCTGTCGCCC

${ }^{\mathrm{b}}$ Statistics from gene time of exercise interaction are showed

${ }^{\mathrm{c}}$ Standard Bruce protocol is a maximal exercise treadmill test

${ }^{\mathrm{d}}$ Statistics from the generalized estimating equations (GEE) tests are shown; Alleles were not mentioned in this article. None reached genomewide significance; however, these were the most suggestive results

${ }^{\mathrm{e}}$ Naughton protocol is a maximal exercise treadmill test

which produces nitric oxide, was associated with heart rate increase during exercise [26]. Although nitric oxide is mostly known for its vasodilatory effects, it is also thought to have a modulating effect on the parasympathetic and sympathetic nervous system [27]. GNAS1 was found to be associated with heart rate increase during exercise as well [28]. This gene encodes the G protein $\alpha$-subunit that influences the sympathetic nervous system as it enables the coupling between adenylyl cyclase and $\beta 1$-adrenergic receptors. On the other hand, many studies brought forward genes based on their direct involvement in the sympathetic nervous system, and associations were found with the $A D R B 1$ [29] and ADRB2 [30] genes, which both encode for $\beta$-adrenergic receptors. Interestingly, many previous findings could not be replicated in the Framingham Offspring study, which investigated multiple genes instead of focusing on a single gene. In this study, associations were found with the ADRAIA and ADRAID [12]. These genes encode for $\alpha$-adrenergic receptors that are mainly involved in smooth muscle cell contraction during sympathetic stimulation [12]. However, associations with the $A D R B 1$ and $A D R B 2$ genes could not be re-established [12]. 


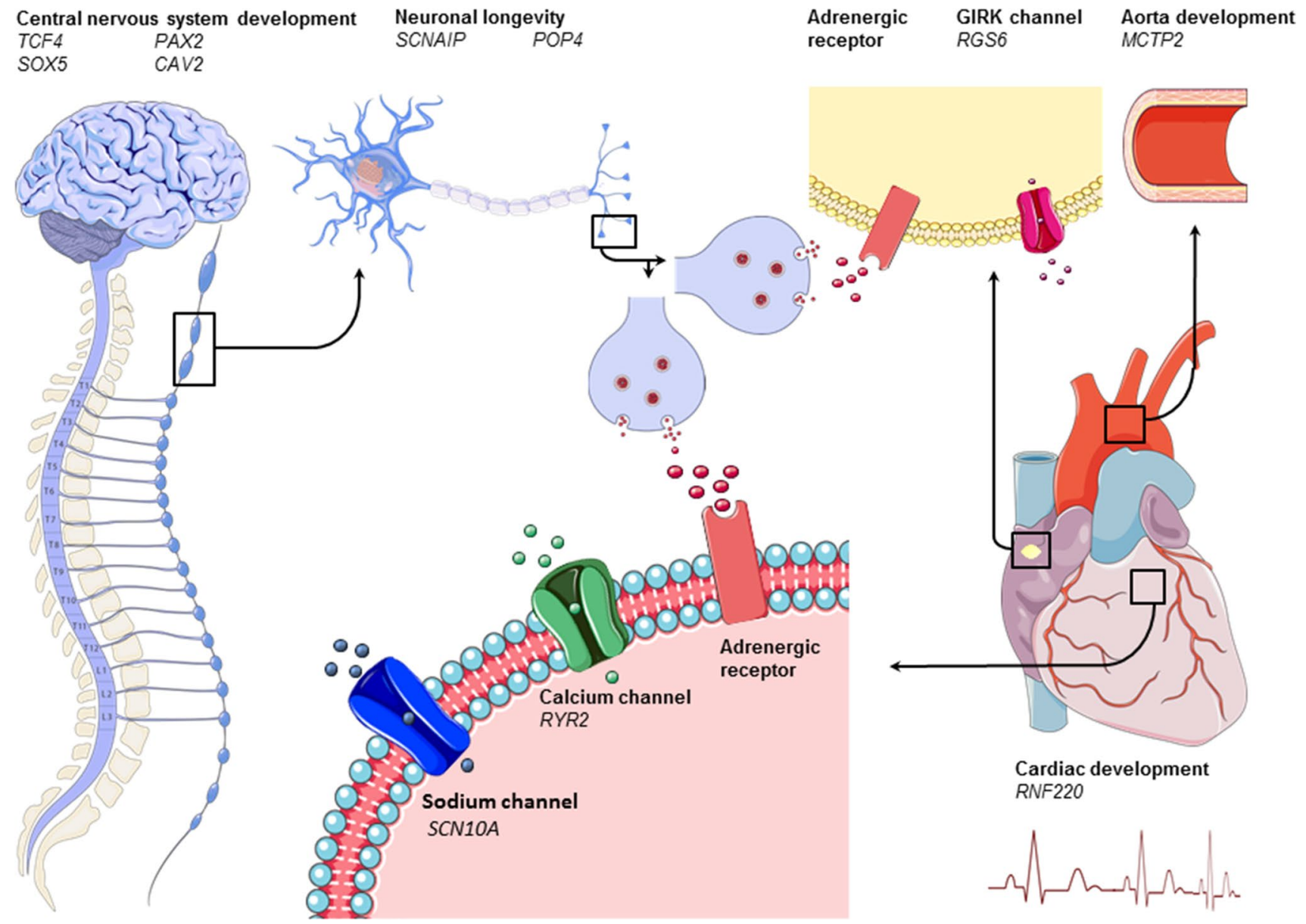

Fig. 1 Graphical representation of genes (shown in italic) involved in acute heart rate increase during exercise grouped by working mechanism (shown in bold). The left and left upper part of the figure shows the nervous system. The middle upper part zooms in on a peripheral sympathetic neuron and its synapse. The heart is displayed on the

Although these studies were important for laying the foundation of our knowledge on the genetic determinants of heart rate increase during exercise, they failed to yield a comprehensive view by focusing on one or only a few genes. The Framingham Offspring study was the first to address these issues by conducting an early genetic linkage analysis on heart rate increase and recovery. However, not one genetic signal reached the appropriate significance level, which can possibly be attributed to the relatively low sample size of this study $(n=2982)$ [12]. In addition, linkage analyses have been shown to be less successful when applied to polygenic traits such as heart rate response to exercise [31], in part because of their limited power to detect the effect of common alleles with modest effects on disease [32].

More recently, genome-wide association studies (GWASs) were introduced. GWASs do have the potential to detect common alleles with modest effects on disease, since this method allows an unbiased and comprehensive right; the upper right of the figure shows the aorta with next to it a pacemaker cell in the cardiac sinus node. In the middle of the figure, below, we zoom in on cardiac tissue and receptors. Adrenergic receptors are shown in red. Sodium, potassium, and calcium channels are shown in red, pink, and green, respectively

search across the genome for single nucleotide polymorphisms (SNPs) [33]. The first GWAS on heart rate increase during exercise found $G A R 1$ and $R Y R 2$ genes to be associated [34]. GARl is required for ribosome biogenesis and telomere maintenance. However, its specific function and how it possibly interacts with heart rate increase during exercise is unknown. $R Y R 2$ encodes a calcium channel that mediates calcium release from the sarcoplasmic reticulum into the cytoplasm and is therefore essential in triggering cardiac muscle contraction (Table 2, Fig. 1). RYR2 mutations in humans are associated with arrhythmogenic rightventricular dysplasia and catecholaminergic polymorphic ventricular tachycardia. Interestingly, although caused by a different mutation in the $R Y R 2$ gene, both diseases are known to cause exercise-induced tachycardia [35-37]. However, these associations did not reach genome-wide significance, which might be due to the low sample size $(n=1238)[34]$. 
Increasing the sample size for GWASs has been simplified by the development of inexpensive SNP arrays. Two GWASs were recently conducted on the acute heart rate response to exercise in the same cohort of the UK Biobank $[14,15]$. The discussion of methodological differences between these studies has been published previously [38] and is beyond the scope of the current review. However, a summary of important differences is necessary to understand different genes found between the two studies. One difference is that the first study by Verweij et al. had a slightly lower sample size, since they used only echocardiography (ECG) measurements and did not include heart rate measurements derived by the UK Biobank itself. Another difference is that the study of Verweij et al. applied a more stringent threshold to claim a genome-wide significant level to be true (strategy to reduce the risk of type-1 errors) compared to the study published later by Ramirez et al. $\left(p<8.3 \times 10^{-9}\right.$ vs $p<5.0 \times 10^{-8}$, respectively).

Of special interest are three genes that were found to be associated with heart rate increase during exercise in both studies, which are SNCAIP, MCTP2, and POP4 [14, 15]. The exact mechanism of SCNAIP is not known so far; however, studies in mice have shown that $S C N A I P$ plays a role in neuronal degeneration (Table 2, Fig. 1) [39, 40]. POP4 is involved in the processing of precursor RNAs [41] and in the DNA damage response [42], thus preventing accumulation of deleterious mutations and DNA lesions and therefore potentially preventing genomic instabilities and carcinogenesis and prolonging neuronal life span. The MCTP2 gene is more specific to cardiac tissue. A mutation in the MCTP2 is known to cause left-ventricular outflow tract malformations in humans, which may alter the pressure within the ventricular outflow tract. Baroreceptors are densely located in this region and altered blood pressure could therefore lead to altered autonomic feedback on heart rate (Table 2, Fig. 1) [43]. Several other candidate genes found in these studies already provide a biological hypothesis to account for the associations with heart rate response to exercise. These genes can be broadly categorized into four categories, that is: (1) development of the nervous system, including the CCDC141 [44, 45], TCF4 [46, 47], PAX2 [48], SOX5 [49, 50], and CAV2 [51] genes; (2) prolongation of neuronal life span, including the SYT10 [52] gene; (3) cardiac development and disease, including RNF220 [53, 54] gene; and, finally, (4) genes involved in cardiac rhythm, including SCN1OA [55] and RGS6 [56, 57]. Of these, CCDC141, $C A V 2, S Y T 10, R N F 220$, and SCN1OA were more strongly associated with heart rate recovery after exercise (Tables 2 , 3 ) and will be therefore discussed later. TCF4 is involved in the initiation of neuronal differentiation. Clinically, a mutation in TCF4 is known to cause Pitt-Hopkins syndrome, a severe congenital encephalopathy characterized by intellectual disability, developmental problems, seizures, breathing problems, and typical facial features [46, 47]. PAX2 encodes paired box gene 2 and is important in the early embryonic development as well. It is mostly known for its involvement in development of the kidney and urinary tract, since it is linked to papillorenal syndrome [58] and focal segmental glomerulosclerosis [59]. However, downstream target effectors of $P A X 2$ have been hypothesized to be involved in neuronal development because of their supposed effect on the CHARGE syndrome [48]. SOX5 is involved in the regulation of chondrogenesis and the development of the nervous system [50]. In mice, it was found that loss of SOX5 resulted in decreased neuronal differentiation and secondary migrational abnormalities [49]. Mutations of the SOX5 gene in humans are known to cause the Lamb-Shaffer syndrome, which is characterized by speech delay, behavioural problems, and nonspecific dysmorphic features [50]. RGS6 is part of the regulation mechanism of the parasympathetic nervous system in the heart $[56,57]$. It decreases muscarinic type 2 receptor (M2R) signalling in the sinoatrial node by rapidly terminating G $\beta \gamma$ signalling [56, 57]. In mice, it was shown that RGS6 knockdown removes the negative regulation of $\mathrm{G} \beta \gamma$ leading to enhanced $\mathrm{G}$ protein-coupled inwardly rectifying potassium channel (GIRK)-induced sinoatrial and atrioventricular node hyperpolarization [56, 57]. It was therefore concluded that normal function of $R G S 6$ is important for preventing parasympathetic override and severe bradycardia [56]. Its involvement in the parasympathetic nervous system was recently established in another GWAS in which it was found to be associated with heart rate variability [60], which is known to reflect parasympathetic activity [61]. Concerning heart rate increase during exercise, normal function of $R G S 6$ probably facilitates parasympathetic withdrawal leading to the possibility to increase heart rate (Fig. 1).

Interestingly, none of the genes investigated in candidate gene studies were found to be associated with heart rate increase in any of the three GWASs. This is in line with the previous work in which early candidate gene studies were difficult to replicate $[62,63]$. Two genes, HMGA2 and PPIL1, shown in Table 2 have not been discussed so far. PPILI is a gene that was recently found to be associated with heart rate variability as well [60]. However, to our knowledge, there is no current biological hypothesis to explain the association between PPIL1 or HMGA2 and heart rate increase during exercise.

\section{Heart rate recovery}

Heart rate recovery is characterized by increased parasympathetic tone followed by sympathetic withdrawal, which follows an inversed gradient pattern compared to heart rate increase [19]. It was elegantly shown in a dual-blockade study that especially parasympathetic reactivation is essential for interindividual differences in heart rate recovery 


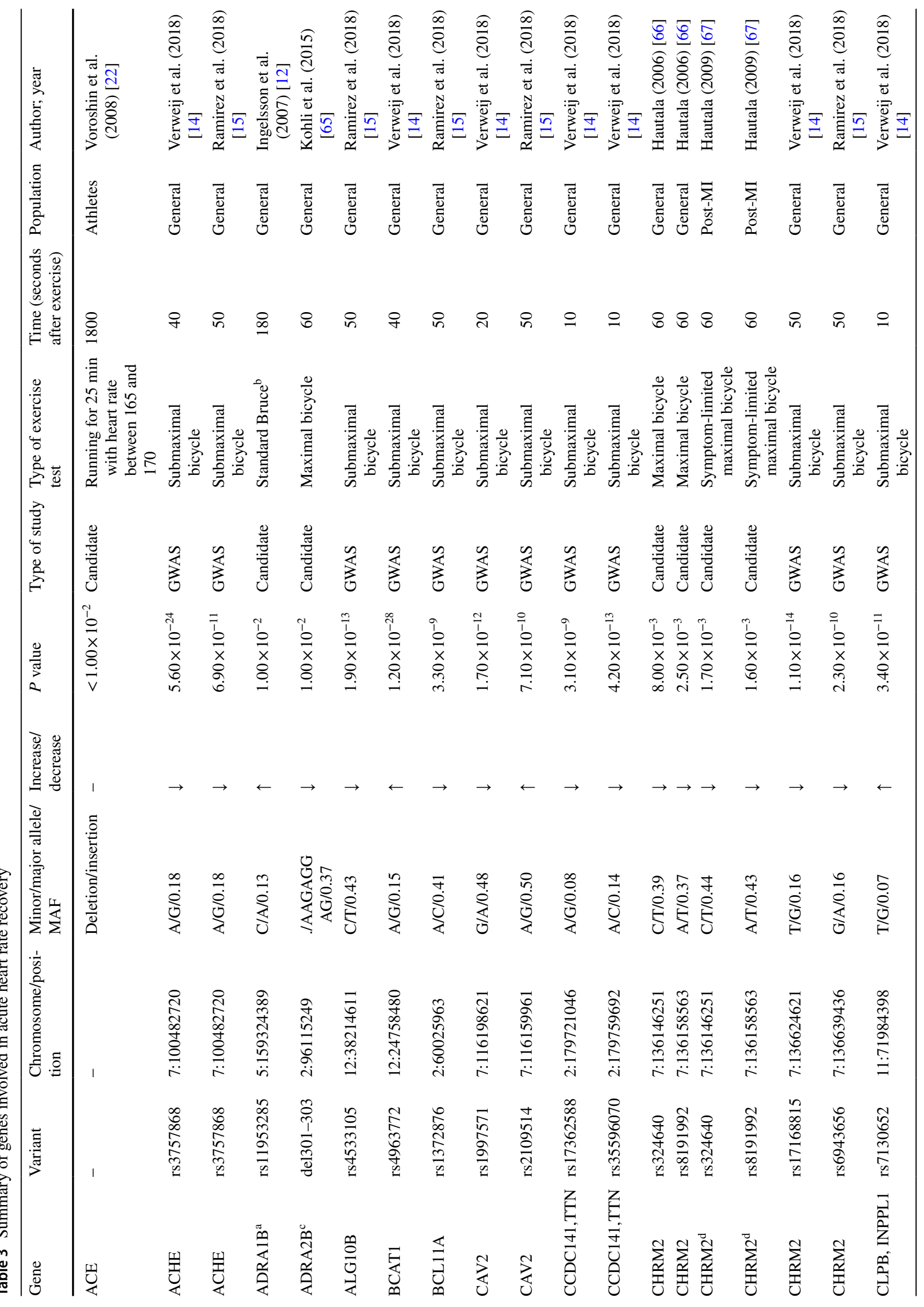




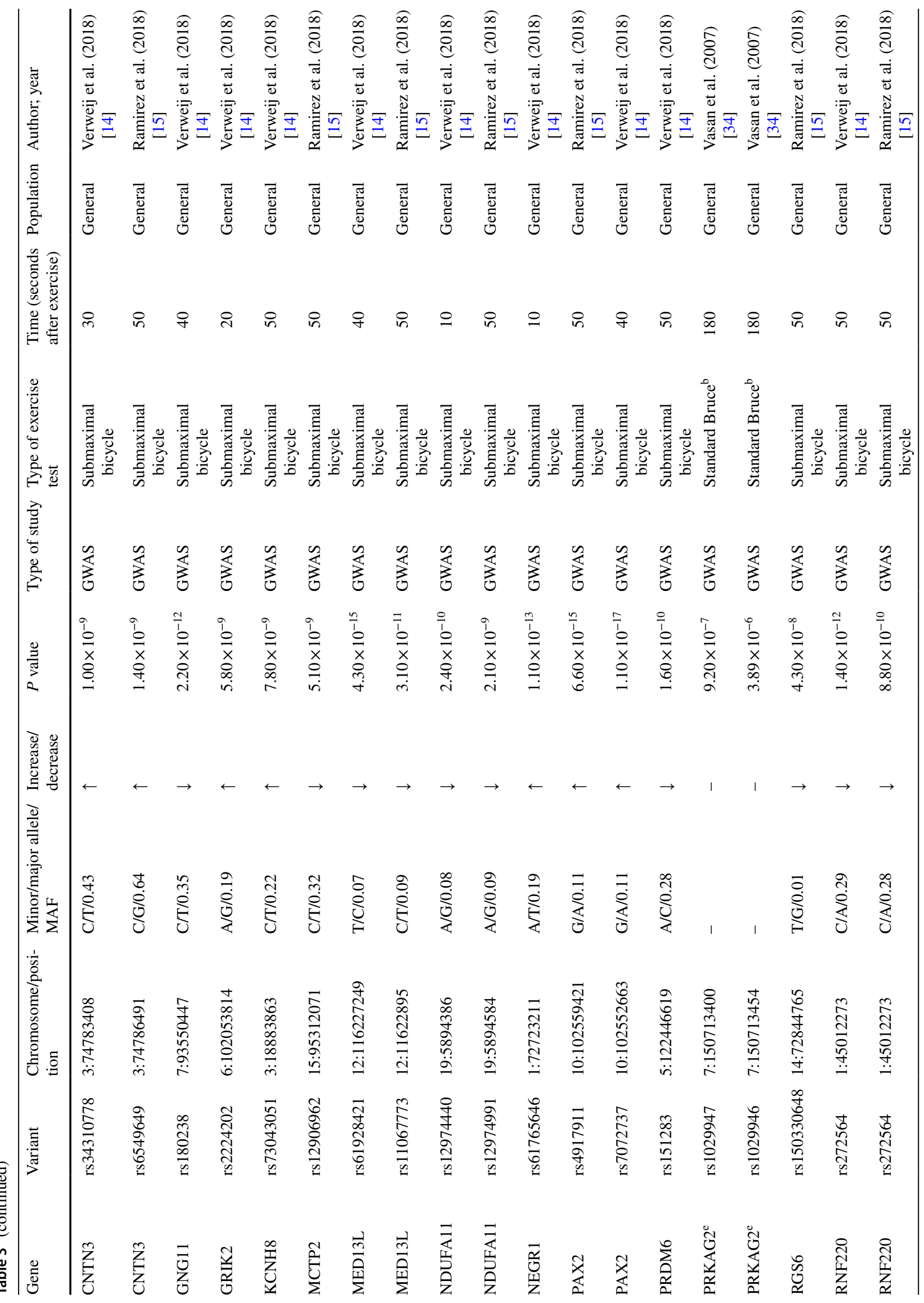




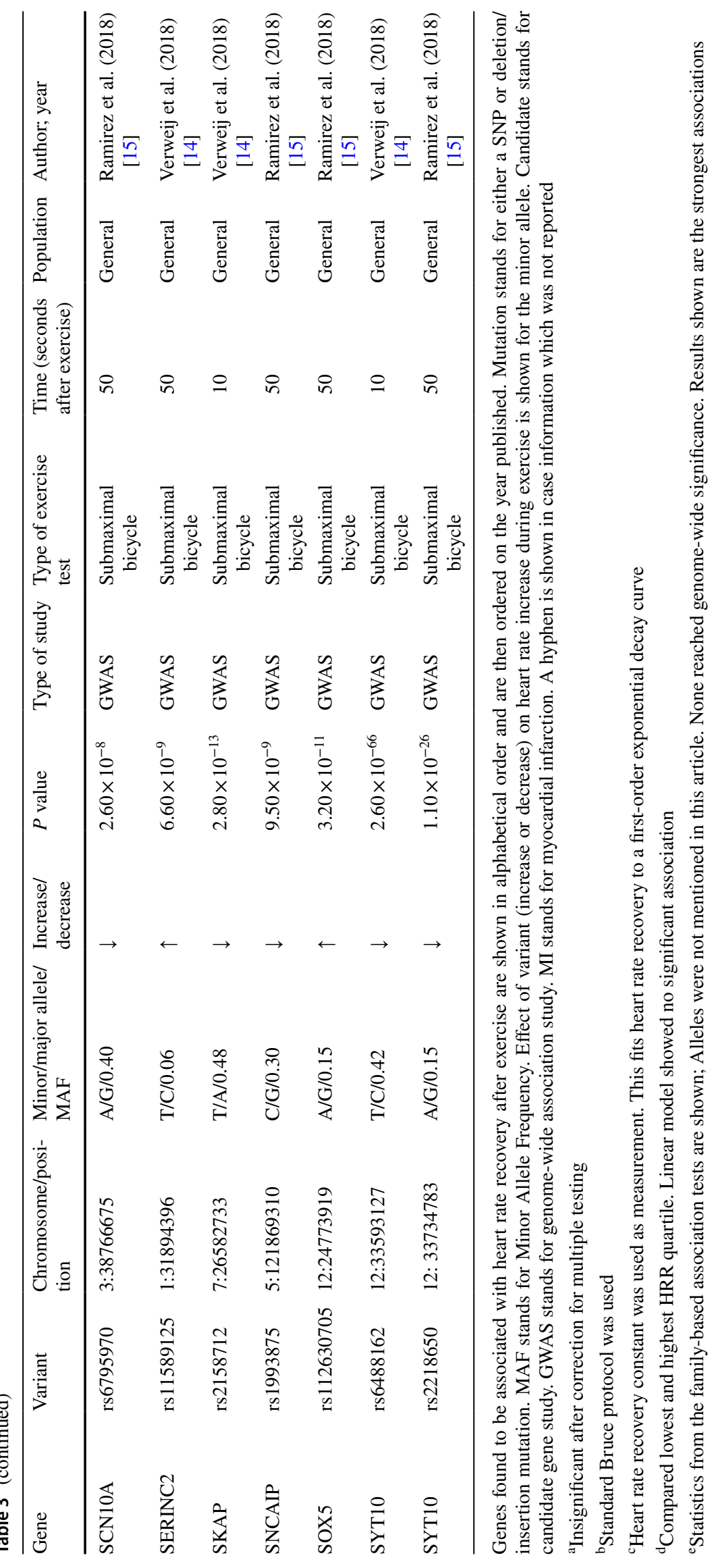


[64]. However, the exact mechanisms underlying these differences remain to be determined. Twin, family, and GWA studies estimated the genetic component to interindividual differences of heart rate recovery after one minute to range between 0.12 and 0.60 (Table 1). Therefore, genetic studies may yield novel insights into heart rate recovery. All genetic determinants investigated for their potential causal role in interindividual differences in heart rate recovery are summarized in Table 3 and are discussed below. An illustration of possible causal genes and how they are supposed to influence acute heart rate recovery after exercise is shown in Fig. 2.

Initially, the same candidate genes were proposed for heart rate recovery as for heart rate increase. For example, the $A C E$ gene was found to be related to heart rate recovery in one candidate gene study as well [22]. Another study found $A D R A 1 B$ and $A D R A 2 B$ to be associated with heart rate recovery (Table 3) [12]. The association between $A D R A 2 B$ gene and heart rate recovery was also found in another candidate gene study [65]. Other studies focused primarily on the parasympathetic nervous system represented by the CHRM2 gene. The minor alleles of the rs 324640 and rs8191992 SNPs found in CHRM2 region were found to be associated with a lower heart rate recovery in the general population [66] and in patients with a history of myocardial infarction [67]. In addition, these minor alleles increased chances of death to coronary artery disease in the latter group [67].

The problem of biased selection of candidate genes has been solved by conducting GWASs as previously stated. The first GWAS on the acute heart rate response to exercise found heart rate recovery measured 3 min post-exercise to be associated with PRKAG2, though this association did not reach genome-wide significance. PRKAG2 is involved in the regulation of ATP restoration after periods of ATP depletion

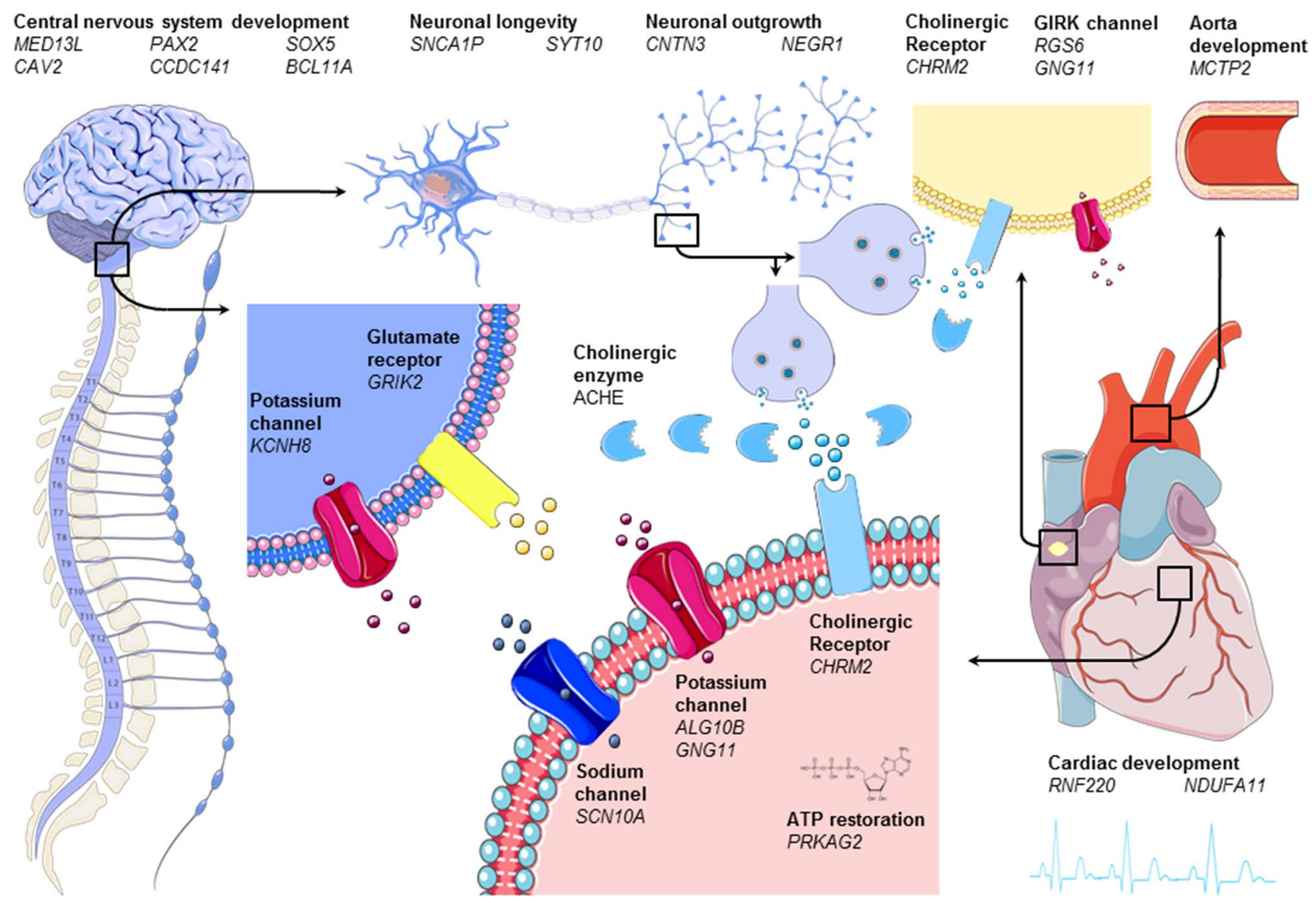

Fig. 2 Graphical representation of genes (shown in italic) involved in acute heart rate recovery after exercise grouped by working mechanism (shown in bold). The left and left upper part of the figure shows the nervous system. The middle upper part zooms in on a parasympathetic neuron of the vagus nerve (twice) and its synapse. Note that although we zoom in on the brain stem (which is the main location of parasympathetic nuclei that innervate the vagus nerve), we actually show a peripheral parasympathetic neuron of the vagus nerve. The heart is displayed on the right; the upper right of the figure shows the aorta with next to it a pacemaker cell in the cardiac sinus node. In the middle of the figure, below, we zoom in on cardiac tissue and receptors. Cholinergic receptors and enzymes are shown in light blue and glutamate receptors in yellow. Sodium and potassium channels are shown in red and pink, respectively 
and therefore might influence the return of heart rate to its initial state (Table 3, Fig. 2).

As previously mentioned, sample size was drastically increased in the two recent studies in the UK Biobank [14, 15]. Some differences between both studies have been discussed earlier (i.e., sample size and genome-wide significant threshold). Concerning heart rate recovery, it is worth mentioning that the phenotype definition was not equal between both studies. The study of Ramirez et al. [15] determined heart rate recovery traditionally as the difference between maximum heart rate and heart rate approximately $1 \mathrm{~min}$ after cessation of exercise. The study of Verweij et al. defined heart rate recovery at five time points, which included the differences between maximum heart rate and heart rate after $50,40,30,20$, and $10 \mathrm{~s}$ after exercise. This includes heart rate recovery at earlier time points (i.e., $10 \mathrm{~s}$ ), which was recently established to be a superior predictor of outcome of all-cause mortality and death by coronary artery disease $[6,7]$.

Interestingly, both studies found the previously investigated candidate gene CHRM2 to be associated with heart rate recovery $[14,15]$. CHRM2 encodes M2R, the main muscarinic cholinergic receptor in the heart. This receptor is known for both its negative chronotropic and inotropic effects after binding with acetylcholine released by postganglionic parasympathetic nerves (Table 3, Fig. 2) [68]. The role of the parasympathetic nervous system in interindividual differences in heart rate recovery is additionally highlighted by the $A C H E$ gene that was found in both studies. $A C H E$ encodes for acetylcholinesterase, an enzyme which breaks down acetylcholine in the synaptic cleft of postganglionic parasympathetic nerves [69]. An increase of acetylcholinesterase would therefore cause an attenuated heart rate recovery by decreasing parasympathetic reactivation. Other genes that were found in both studies were SYT10, CNTN3, $P A X 2, C A V 2, M E D 13 L, R N F 220$, and NDUFA11 (Table 3, Fig. 2). SYT10 encodes a $\mathrm{Ca}^{2+}$ sensor synaptotagmin 10 that triggers IGF-1 exocytosis, which, in turn, protects neurons from degeneration. SYT10 might play an important role in the regulation of heart rate, as it was found to be associated with resting heart rate [3, 23], heart rate increase [15], and heart rate variability [60] as well. CNTN3 belongs to a group of glycosylphosphatidyl-anchored cell adhesion molecules that are mostly found in neurons [70, 71]. Because of its similarity with $T A G-1$, it is thought to have an important function in neuronal outgrowth and wiring of the nervous system [70-72]. In the study of Ramirez et al. it was found that the allele of one SNP decreased heart rate recovery and increased CNTN3 expression levels in the nucleus accumbens [15]. Since heart rate recovery is mainly influenced by the parasympathetic nervous system [64], it was hypothesized that CNTN3 may also be relevant to cardiac parasympathetic modulation [15]. However, it is more likely to be associated with cardiac sympathetic modulation, since morphology of the nucleus accumbens has been shown to be correlated with cardiac sympathetic index [73]. PAX2 is known to be the first gene to be expressed in the mid- and hindbrain during embryonal developments in mice [74] and can be found in the hindbrain in the early stages of embryo development in humans as well [48]. The hindbrain includes the nucleus tractus solitarius, nucleus ambiguous, and dorsal nucleus of the vagus, which are known to mainly influence cardiac parasympathetic innervation of the heart through vagus nerve stimulation [75]. Less is known about $C A V 2$, which was found to be associated with heart rate response to exercise as well. However, one study pointed out that $C A V 2$ is necessary for differentiation of dorsal root ganglion cells during the early differentiating programs [51]. The function of $M E D 13 L$ is unclear as well, but knockdown in zebrafish caused abnormal neural-crest cell migration [76]. This is supported by clinical characteristics in humans with $M E D 13 L$ mutations, which can be characterized by intellectual disabilities, developmental delay, and craniofacial anomalies [77]. RNF220 functions as an E3 ubiquitin ligase, which determines protein target specificity during posttranslational ubiquitination [53]. A possible link with heart rate recovery originates from the involvement of RNF22O in the canonical WNT signalling cascade. In a knockdown study, $R N F 220$ was shown to stabilize $\beta$-catenin by interacting with ubiquitin-specific peptidase Usp7 [54]. This stabilizing function is important, because the $\mathrm{WNT} / \beta$-catenin signalling pathway is involved in embryonic cardiac development [78], the development of cardiac disease [79-81], and in cardiac repair [80]. NDUFA11 is an accessory subunit of the mitochondrial membrane respiratory chain NADH dehydrogenase complex I. In humans, a splice-site mutation in this gene is known to cause mitochondrial complex I deficiency. This can cause a wide range of disorders, including encephalocardiomyopathy [82]. Recently, it was shown that downregulation of NDUFA11 by small interfering RNA reduced ATP production and increased mitochondria reactive oxygen species production in cardiac mitochondria of mice [83]. NDUFA11 was found to be associated with heart rate variability as well, suggesting that it is an important factor in causing differences between individuals' heart rate response [60].

Other candidate genes found in one of the GWASs provide a biological hypothesis for their possible causal role in interindividual differences in heart rate recovery as well. These genes include CCDC141, BCL11A, KCNH8, $A L G 10 B, G N G 11, G R I K 2$, and NEGR1. CCDC141 is a gene that plays a central role in neuronal development $[44,45]$. In fact, in utero knockdown of $C C D C 141$ in mice resulted in impaired radial migration in [44]. The same applies to $B C L 11 A$, which encodes a $\mathrm{C} 2 \mathrm{H} 2$-type zincfinger protein that is involved in neuronal development. 
Studies in mice have shown that slowed migration of neurons upon knockdown resulted in microcephaly with decreased brain volume [84], particularly affecting the limbic system [85]. Within the human brain, it is most highly expressed in the caudate nucleus followed by hippocampus [86]. In humans, different de novo heterozygous mutations have been found to cause developmental disorder with persistence of fetal haemoglobin [85]. KCNH8 encodes a voltage-gated potassium channel. It is mainly expressed in the central nervous system and is involved in the regulation of neuronal excitation (Table 3 , Fig. 2) [87-89]. $A L G 10 B$ is involved in potassium regulation, as well, since it is a potassium channel regulator that couples to $\mathrm{KCNH} 2$. However, it is more involved in cardiac tissue than neuronal tissue and is known for its influence on heart rhythm. Upon binding with $K C N H 2$, it reduces sensitivity to classic proarrhythmic drug blockade [90]. GNG11 encodes the $\gamma 11$ subunit of the heterotrimeric G protein complex $\mathrm{G} \alpha \beta \gamma$ [91]. GNG11 is just as $R G S 6$ thought to be involved in GIRK activation and was found to be associated with heart rate variability [60] as well. In this study, it was hypothesized that variations in this gene lower the availability of the $\gamma 11$ subunit, thereby reducing G $\alpha \beta \gamma$ component-induced GIRK activation [60]. This would lead to decreased heart rate variability through attenuated response to changes in cardiac vagal activity [60]. If true, the same would apply for heart rate recovery; decreased response to cardiac vagal reactivation after exercise would translate to blunted heart rate recovery. In addition, another mutation in the RGS6 gene in humans was shown to decrease susceptibility to the long QT syndrome [92]. GRIK2 encodes a glutamate receptor that is mostly expressed in the human cerebral and cerebellar cortices [93]. Here, it is involved in neuronal excitation and plays an important role in a variety of normal neurophysiologic processes. Neuronal Growth Regulator 1 (NEGRI) is essential for neuronal morphology and, just as $C N T N 3$, has been shown to regulate neurite outgrowth (Table 3, Fig. 2) [94]. Perhaps because of this essential function, NEGRl has been associated with many polygenetic traits, including body mass index, years of education, and physical activity.

Heart rate increase and recovery share a high genetic correlation and it is therefore likely that there is overlap in genes that were found for both aspects of the heart rate response to exercise [14]. SNCAIP, SOX5, RGS6, and $M C T P 2$ genes were already discussed for heart rate increase during exercise because of their stronger association with this phenotype.

BCAT1, CLPB, PRDM6, SKAP, and SERINC2 are also shown in Table 3, but have not been discussed yet. To our knowledge, these genes could not be linked to heart rate recovery after exercise on a biological basis so far.

\section{Long-term modification of the heart rate response to exercise}

\section{Heart rate increase}

Regular endurance exercise training is known to shift the cardiac autonomic balance towards vagal dominance [10] and, as a consequence, diminish submaximal heart rate when an individual cycles at the same intensity [11]. Large interindividual differences were observed for submaximal heart rate training response [95] and heritability analysis estimated a genetic component ranging between 0.34 and 0.36 (Table 1) [16, 17]. Therefore, several studies were conducted to gain insights in the causes of these interindividual differences. The first study in the HERITAGE family cohort found a heritability of 0.34 for exercise heart rate changes to regular training, with the strongest linkage on chromosome 2q33.3-q34 [17]. Next, this region was fine-mapped and it was found that the CREB1 gene locus was strongly associated with submaximal exercise heart rate training response [96]. Nonetheless, it only explained $5.45 \%$ of the $34 \%$ heritability [96].

To gain further insights in the genes causing the remaining fraction of its heritability, a GWAS was performed in the HERITAGE family cohort. In this study, nine SNPs were identified and accounted for the total of $34 \%$ heritability of exercise-induced changes to heart rate increase [97]. The most significantly associated SNP was linked to the $Y W H A Q$ gene (Table 4). YWHAQ is mostly expressed in the brain, heart, and pancreas [98], and its main function is apoptosis and cell proliferation. It was shown that the cardiac-specific mutated $Y W H A Q$ gene leads to increased pathological ventricular remodelling with increased cardiomyocyte apoptosis after experimental myocardial infarction [99]. It can be hypothesized that mutations in the $Y W H A Q$ gene lead to similar pathological cardiac remodelling after exercise training, causing diminished exercise-induced changes to heart rate increase. However, a neurological causal pathway cannot be ruled out, since the same mechanism could apply to neuronal remodelling needed to attenuate heart rate increase after regular exercise training [11].The CREBI gene (Table 4) was significantly associated with submaximal heart rate response to exercise training as well [97]. In this study, it was hypothesized that $C R E B 1$ altered the exercise-induced changes in heart rate increase due to its effect on either cardiac [100] or neuronal memory [101]. Cardiac memory is a phenomenon in which an altered $\mathrm{T}$ wave on electrocardiogram can be seen when sinus rhythm restarts after a period of abnormal rhythm, for example, after ventricular pacing or arrhythmia [100]. The other hypothesis involving neuronal memory fits in our current understanding that neuron biology is of great importance in the heart rate response 
Table 4 Summary of genes involved in the long-term heart response to exercise

\begin{tabular}{|c|c|c|c|c|c|c|c|c|}
\hline Gene & Variant & $\begin{array}{l}\text { Chromosome/ } \\
\text { position }\end{array}$ & $P$ value & Type of study & Training schedule & $\begin{array}{l}\text { Type of exercise } \\
\text { test }\end{array}$ & Population & Author; year \\
\hline \multicolumn{9}{|c|}{ Heart rate increase } \\
\hline $\mathrm{CREB}^{\mathrm{a}}{ }^{\mathrm{a}}$ & rs2253206 & $2: 208100223$ & $1.6 \times 10^{-5}$ & GWAS & $\begin{array}{l}20 \text { weeks, } 3 \\
\text { times a day, } \\
30-50 \text { min at } \\
\text { submaximal HR }\end{array}$ & $\begin{array}{l}\text { Submaximal } \\
\text { bicycle }\end{array}$ & $\begin{array}{l}\text { Healthy, but } \\
\text { sedentary }\end{array}$ & $\begin{array}{l}\text { Rankinen et al. } \\
\text { (2012) [97] }\end{array}$ \\
\hline $\mathrm{GCH} 1^{\mathrm{a}}$ & rs2057368 & 14:54373759 & $5.6 \times 10^{-5}$ & GWAS & $\begin{array}{l}20 \text { weeks, } 3 \\
\text { times a day, } \\
30-50 \text { min at } \\
\text { submaximal HR }\end{array}$ & $\begin{array}{l}\text { Submaximal } \\
\text { bicycle }\end{array}$ & $\begin{array}{l}\text { Healthy, but } \\
\text { sedentary }\end{array}$ & $\begin{array}{l}\text { Rankinen et al. } \\
\text { (2012) [97] }\end{array}$ \\
\hline GPRIN3 $^{\mathrm{a}}$ & rs 1560488 & $4: 90444858$ & $3.3 \times 10^{-5}$ & GWAS & $\begin{array}{l}20 \text { weeks, } 3 \\
\text { times a day, } \\
30-50 \text { min at } \\
\text { submaximal HR }\end{array}$ & $\begin{array}{l}\text { Submaximal } \\
\text { bicycle }\end{array}$ & $\begin{array}{l}\text { Healthy, but } \\
\text { sedentary }\end{array}$ & $\begin{array}{l}\text { Rankinen } \\
\text { et al. (2012) [97] }\end{array}$ \\
\hline RBPMS $^{\mathrm{a}}$ & rs2979481 & $8: 30382328$ & $3.8 \times 10^{-6}$ & GWAS & $\begin{array}{l}20 \text { weeks, } 3 \\
\text { times a day, } \\
30-50 \text { min at } \\
\text { submaximal HR }\end{array}$ & $\begin{array}{l}\text { Submaximal } \\
\text { bicycle }\end{array}$ & $\begin{array}{l}\text { Healthy, but } \\
\text { sedentary }\end{array}$ & $\begin{array}{l}\text { Rankinen et } \\
\quad \text { al. (2012) [97] }\end{array}$ \\
\hline MYLIP & rs909562 & $6: 16238312$ & $3.2 \times 10^{-5}$ & GWAS & $\begin{array}{l}20 \text { weeks, } 3 \\
\text { times a day, } \\
30-50 \text { min at } \\
\text { submaximal HR }\end{array}$ & $\begin{array}{l}\text { Submaximal } \\
\text { bicycle }\end{array}$ & $\begin{array}{l}\text { Healthy, but } \\
\text { sedentary }\end{array}$ & $\begin{array}{l}\text { Rankinen et al. } \\
\text { (2012) [97] }\end{array}$ \\
\hline OR6N2 $2^{a}$ & rs 857838 & $1: 157017174$ & $7.6 \times 10^{-5}$ & GWAS & $\begin{array}{l}20 \text { weeks, } 3 \\
\text { times a day, } \\
30-50 \text { min at } \\
\text { submaximal HR }\end{array}$ & $\begin{array}{l}\text { Submaximal } \\
\text { bicycle }\end{array}$ & $\begin{array}{l}\text { Healthy, but } \\
\text { sedentary }\end{array}$ & $\begin{array}{l}\text { Rankinen et al. } \\
\text { (2012) [97] }\end{array}$ \\
\hline PIWIL1 $^{\mathrm{a}}$ & rs4759659 & $12: 129403241$ & $5.7 \times 10^{-5}$ & GWAS & $\begin{array}{l}20 \text { weeks, } 3 \\
\text { times a day, } \\
30-50 \text { min at } \\
\text { submaximal HR }\end{array}$ & $\begin{array}{l}\text { Submaximal } \\
\text { bicycle }\end{array}$ & $\begin{array}{l}\text { Healthy, but } \\
\text { sedentary }\end{array}$ & $\begin{array}{l}\text { Rankinen et al. } \\
\text { (2012) [97] }\end{array}$ \\
\hline TFEC $^{\mathrm{a}}$ & rs10248479 & $7: 115395591$ & $3.4 \times 10^{-5}$ & GWAS & $\begin{array}{l}20 \text { weeks, } 3 \\
\text { times a day, } \\
30-50 \text { min at } \\
\text { submaximal HR }\end{array}$ & $\begin{array}{l}\text { Submaximal } \\
\text { bicycle }\end{array}$ & $\begin{array}{c}\text { Healthy, but } \\
\text { sedentary }\end{array}$ & $\begin{array}{l}\text { Rankinen et al. } \\
\text { (2012) [97] }\end{array}$ \\
\hline YWHAQ $^{\mathrm{a}}$ & rs6432018 & $2: 9639347$ & $8.1 \times 10^{-7}$ & GWAS & $\begin{array}{l}20 \text { weeks, } 3 \\
\text { times a day, } \\
30-50 \text { min at } \\
\text { submaximal HR }\end{array}$ & $\begin{array}{l}\text { Submaximal } \\
\text { bicycle }\end{array}$ & $\begin{array}{l}\text { Healthy, but } \\
\text { sedentary }\end{array}$ & $\begin{array}{l}\text { Rankinen et al. } \\
\text { (2012) [97] }\end{array}$ \\
\hline \multicolumn{9}{|c|}{ Heart rate recovery } \\
\hline $\mathrm{CHRM}^{\mathrm{b}}$ & rs 324640 & $7: 136146251$ & 0.008 & Candidate & $\begin{array}{c}2 \text { weeks, } 5 \text { times a } \\
\text { week, } 40 \mathrm{~min} \text { at } \\
\text { submaximal HR }\end{array}$ & Maximal bicycle & $\begin{array}{l}\text { Healthy, but } \\
\text { sedentary }\end{array}$ & $\begin{array}{l}\text { Hautala (2006) } \\
\text { [66] }\end{array}$ \\
\hline $\mathrm{CHRM}^{\mathrm{b}}$ & rs8191992 & $7: 136158563$ & 0.005 & Candidate & $\begin{array}{c}2 \text { weeks, } 5 \text { times a } \\
\text { week, } 40 \mathrm{~min} \text { at } \\
\text { submaximal HR }\end{array}$ & Maximal bicycle & $\begin{array}{l}\text { Healthy, but } \\
\text { sedentary }\end{array}$ & $\begin{array}{l}\text { Hautala (2006) } \\
\text { [66] }\end{array}$ \\
\hline
\end{tabular}

Genes found to be associated with changes in training-induced changes to heart rate increase and recovery are shown in alphabetical order. Variant stands for either a SNP or deletion/insertion mutation. Candidate stands for candidate gene study. GWAS stands for genome-wide association study

${ }^{a}$ Allele frequencies and betas are not mentioned in this study and direction (in- or decrease of response to training) can, therefore, not be determined

${ }^{\mathrm{b}}$ Minor alleles of rs324640 and rs8191992 (respectively, A and C) decreased heart rate recovery

to exercise. Neuronal memory or long-term potentiation is a form of synaptic plasticity in which there is a longlasting increase of synaptic strength in case the synapse is highly active. It could be hypothesized that regular exercise causes an increase of synaptic strength of parasympathetic neurons, thus altering the heart rate increase during exercise. However, CREBI encodes a transcription factor that regulates many mechanisms in the body and its association with memory does not imply causality. A recent editorial rightfully addressed the fact that the same allele in another study was found to increase the rise of temperature [102] and, therefore, might decrease subjective liking of exercise training, potentially diminishing motivation [103]. 


\section{Heart rate recovery}

On the other hand, heart rate recovery increases when the cardiac autonomic balance shifts towards vagal dominance after regular endurance training [10]. Little research has been performed on the genetics of training-induced changes to heart rate recovery, although a heritable component has been suggested [66]. To our knowledge, only one study has been conducted on this subject. In this candidate gene study, it was found that the CHRM2 gene (Table 4) is linked to long-term modification of heart rate recovery to exercise training as well [66]. Participants who had a the minor alleles of the rs324640 and rs8191992 SNPs were not only found to have a lower acute heart rate recovery, but also showed less increase in heart rate recovery after regular endurance training. As previously mentioned, CHRM2 encodes the muscarinic acetylcholine receptor M2R and, upon activation, causes a negative chronotropic and inotropic response. It therefore seems that genetic variation in CHRM2 not only causes interindividual differences in acute heart rate recovery [68], but also in long-term modifications. A full overview of the genes discussed for the long-term heart rate response to exercise can be found in Table 4 .

\section{Association of heart rate response to exercise-related genes with other traits}

We assessed the association of described genes with other traits in publicly available GWASs using the GWAS catalogue (Online Resource 1). In short, the candidate causal genes that were associated with both heart rate increase and recovery were also associated with resting heart rate (CCDC141, RGS6, RNF220, SCN10A, and SYT10), heart rate variability (CCDC141, RGS6, RNF220, and SYT10), blood pressure (CCDC141 and $P A X 2)$, atrial fibrillation (CAV2 and SCN1OA), coronary artery disease (CAV2 and $S C N 10 A)$, and ECG traits including the PR interval (CAV2 and SCN1OA), QRS duration, and the Brugada syndrome (both SN1OA).

Some genes that were only associated with heart rate increase during exercise were found to be associated with resting heart rate and heart rate variability (PPIL1), blood pressure (ADRB1, ACE, NOS3, and HMGA2), atrial fibrillation (MCTP2 and NOS3), exercise treadmill test and lung function (both $R Y R 2$ ). Similarly, some of the heart rate recovery genes were also associated with resting heart rate ( $A C H E$ and $G N G 11$ ), heart rate variability (GNG11 and NDUFA11), blood pressure (PRDM6, PRKAG2, and CHRM2), QRS duration, (PRDM6), atrial fibrillation and coronary artery disease (BCL1 1A, PRDMO), and obesity and vigorous physical activity levels (both $N E G R I$ ).

\section{Future directions}

Improvement of prevention and treatment of disease in the human health sector is the ultimate application of novel knowledge found by genetic studies and future research should be performed to achieve this goal (Fig. 3) [104]. Functional follow-up of findings obtained by GWAS will be necessary to gain insights in how likely causal genes affect the heart rate response to exercise [104]. Most genes that were prioritized so far have a plausible biological mechanism in which they influence the heart rate response to exercise. However, the exact effect of all genes on exerciseinduced heart rate changes could be validated in an experimental setting (Fig. 3). One possible method is to perform functional experiments in cardiomyocytes obtained from embryonic stem cells [105]. In cardiomyocytes, human diseases and risk factors with their underlying genetic contribution can be created in vitro [105]. Since cardiomyocyte cell cultures can beat spontaneously [105], simulating the effect of this genetic contribution allows for investigation of the acute heart rate response to pacing from resting to exercise heart rate levels in small cell cultures. In addition, by simulating the effect of this genetic contribution, drugs can be screened against an individual's full genetic backgrounds to discover information on cardiotoxicity for each individual. This could potentially give insights in the development of personalized medicine strategies for heart rate modification [106], which is an essential strategy in the treatment of coronary artery disease [107] and heart failure (Fig. 3) $[108,109]$. Genes known to affect cardiac de- and repolarisation (RYR2, ALG10B, and SCN1OA) or GIRK channels in the cardiac sinus node ( $R G S 6$ and GNG11) could be of interest to study in this setting. Recent development in the generation of spinal human cord neural cells could provide the same opportunity for investigating neuronal cell longevity including genes such as SCNAIP, POP4, and SYT1O [110]. Complex neurological mechanisms at the interplay of the sympathetic and parasympathetic nervous system (i.e., KCNH8 and GRIK2) or neuronal development (i.e., SOX5, $P A X 2$, and $B C L 11 A$ ) are more difficult to investigate using this method. This can be solved by investigating these genes using in vivo models of animals that share a high percentage of their genomic pattern with humans, including mice [111, 112], fruit flies [113], and zebrafish [114] (Fig. 3). For example, knockdown of RGS6 [56, 57], MED13L [76], and $B C L 11 A$ [85] has already provided insights in biological consequences of mutations in these genes.

Improvement of prevention of disease is another goal of genetic research. While accurate risk prediction might be relatively straightforward for mono- and oligogenic disease, this is more difficult for polygenic diseases such as coronary artery disease and heart failure. However, the 


\section{Experimental validation Human application}

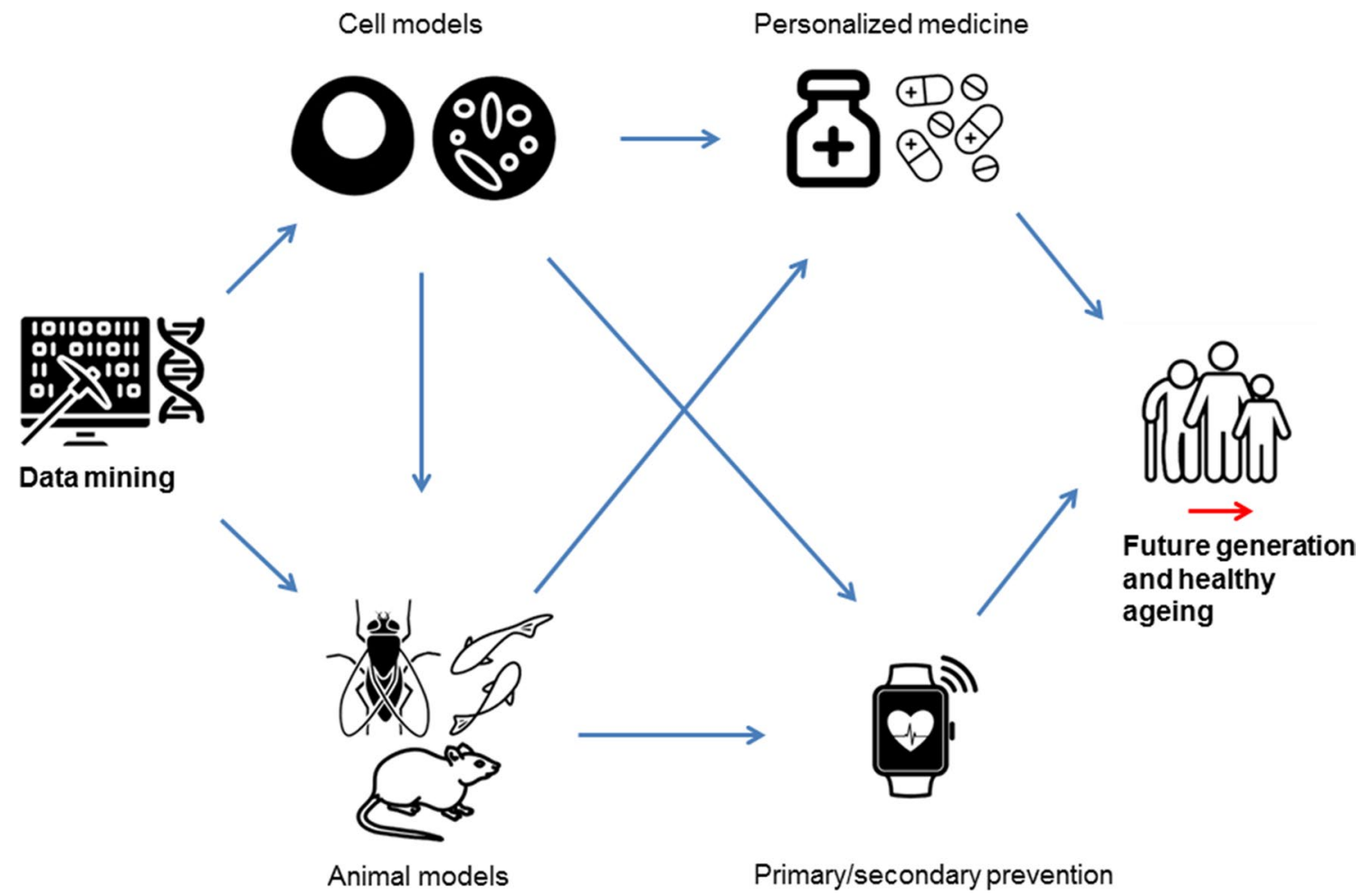

Fig. 3 Possible follow-up of GWAS on heart rate response to exercise. Cell models based on pluripotent stem cells provide a potential functional model to study GWAS findings using experimental manipulations that cannot be performed in vivo. Complex mechanisms of genetic interplay could be studied in animals that share a high percentage of their genomic sequence with humans, including mice,

knowledge on genetic variants obtained by GWAS can be used to construct genetic risk cores by summing the number of risk alleles weighted by the corresponding beta coefficients. Recently, it was shown that the polygenic risk score of coronary artery disease had the ability to identify $8.0 \%$ of the population at greater than threefold risk for coronary artery disease [115]. These individuals can subsequently be selected for encouragement of behavioural lifestyle changes as relative effects of poor lifestyle were shown to be comparable between genetic risk groups [116]. Similar to the traditional risk score models in which several traditional risk phenotypes are used to predict risk events, this could ultimately be performed for genetic risk score models as well. As previously stated, there is a large body of observational studies that links heart rate response to exercise to all-cause mortality and cardiovascular disease in healthy individuals and those with a history of cardiac disease [5-9]. In this light, it would be interesting to see whether adding the polygenetic risk scores for the acute heart rate response to exercise into a genetic risk score model that includes the polygenetic risk score for the cardiovascular disease itself fruit flies, and zebrafishes. Tools such as gene knockdowns can be used to manipulate the genomes of these animal models. The ultimate application of knowledge initiated by GWAS findings in heart rate response to exercise lies in the improvement of primary and secondary prevention and personalized medicine to improve human health

could improve detection of individuals at high risk of disease. However, it should be noted that both recent GWAS on the acute heart rate response to exercise did not find support for a genetic association with cardiovascular mortality [14, 15]. The lack of an association in both studies might originate from the fact that a small replication cohort consisting of a relatively young and healthy population was used. The study of Verweij et al. [14] did find a significant association between heart rate response to exercise and parental age as proxy for all-cause mortality. However, first, it is required to investigate whether there is a genetic association with cardiovascular disease and all-cause mortality, preferably in a larger independent cohort [117].

The evidence on long-term modification of the heart rate response to exercise is limited so far [97]. If the genetics of the acute heart rate response to exercise can be used to predict cardiovascular mortality, the combination with information on the genetics of the long-term modification of the heart rate response to exercise could one day inform the choice of prevention strategy. For example, a high genetic risk score for a diminished acute response to exercise combined with a genetic 
risk score that indicates high training-induced changes to heart rate response could be an indicator of early primary or secondary prevention strategies (Fig. 3). On the other hand, a high genetic risk score for a diminished acute response to exercise combined with a genetic risk score that indicates little traininginduced changes could be an indication of early intervention through medication (Fig. 3).

\section{Conclusion}

In the current review, we found a total of 10 genes associated with the acute heart rate response to exercise in candidate gene studies. Only one gene (CHRM2), related to heart rate recovery, was replicated in recent GWASs. Additional 17 candidate causal genes were identified for heart rate increase and 26 for heart rate recovery in these GWASs. Nine of these genes were associated with both acute heart rate increase and recovery during exercise. These genes can be broadly categorized into four categories: (1) development of the nervous system (CCDC141, PAX2, SOX5, and CAV2); (2) prolongation of neuronal life span (SYT10); (3) cardiac development (RNF220 and MCTP2), and (4) cardiac rhythm (SCNIOA and RGS6). Of the total of 43 genes, nine showed overlap with resting heart rate and heart rate variability, six with atrial fibrillation and coronary artery disease, two with ECG traits, and nine with blood pressure. The current findings support the idea that the autonomic nervous system is a major player in the regulation of the acute heart rate response to exercise. Heart rate recovery is especially influenced by parasympathetic nervous system genes ( $A C H E$ and $C H R M 2$ ), in line with the previous research [64]. Regarding the long-term response to exercise, heart rate increase during exercise was found to be mainly associated with genes involved in either cardiac or neuronal remodelling. Little evidence has been found for the long-term response of heart rate recovery to exercise, except for parasympathetic involvement. Future work will be required to translate these findings to preventive and therapeutic applications.

Funding N. Verweij is supported by "Nederlandse Organisatie voor Wetenschappelijk Onderzoek" VENI grant (016.186.125) in support of research into ECG changes in response to exercise.

\section{Compliance with ethical standards}

Conflict of interest The authors declare that they have no conflict of interest. Author N. Verweij is an employee of Genomics plc.

Open Access This article is distributed under the terms of the Creative Commons Attribution 4.0 International License (http://creativeco mmons.org/licenses/by/4.0/), which permits unrestricted use, distribution, and reproduction in any medium, provided you give appropriate credit to the original author(s) and the source, provide a link to the Creative Commons license, and indicate if changes were made.

\section{References}

1. Hammond HK, Froelicher VF (1985) Normal and abnormal heart rate responses to exercise. Prog Cardiovasc Dis 27:271-296

2. Bahrainy S, Levy WC, Busey JM et al (2016) Exercise training bradycardia is largely explained by reduced intrinsic heart rate. Int J Cardiol 222:213-216. https://doi.org/10.1016/j.ijcar d.2016.07.203

3. Eppinga RN, Hagemeijer Y, Burgess S et al (2016) Identification of genomic loci associated with resting heart rate and shared genetic predictors with all-cause mortality. Nat Genet 48:1557-1563. https://doi.org/10.1038/ng.3708

4. Fletcher GF, Balady GJ, Amsterdam EA et al (2001) Exercise standards for testing and training: a statement for healthcare professionals from the American Heart Association. Circulation 104:1694-1740

5. Jouven X, Empana J-P, Schwartz PJ et al (2005) Heart-rate profile during exercise as a predictor of sudden death. N Engl J Med 352:1951-1958. https://doi.org/10.1056/NEJMoa0430 12

6. McCrory C, Berkman LF, Nolan H et al (2016) Speed of heart rate recovery in response to orthostatic challenge novelty and significance. Circ Res 119:666-675. https://doi.org/10.1161/ CIRCRESAHA.116.308577

7. van de Vegte YJ, van der Harst P, Verweij N (2018) Heart rate recovery 10 seconds after cessation of exercise predicts death. J Am Heart Assoc 7:e008341. https://doi.org/10.1161/ JAHA.117.008341

8. Arena R, Myers J, Abella J et al (2010) The prognostic value of the heart rate response during exercise and recovery in patients with heart failure: influence of beta-blockade. Int J Cardiol 138:166-173. https://doi.org/10.1016/j.ijcard.2008.08.010

9. Dresing TJ, Blackstone EH, Pashkow FJ et al (2000) Usefulness of impaired chronotropic response to exercise as a predictor of mortality, independent of the severity of coronary artery disease. Am J Cardiol 86:602-609. https://doi.org/10.1016/S0002 -9149(00)01036-5

10. Hautala AJ, Mäkikallio TH, Kiviniemi A et al (2004) Heart rate dynamics after controlled training followed by a home-based exercise program. Eur J Appl Physiol 92:289-297. https://doi. org/10.1007/s00421-004-1077-6

11. Brubaker PH, Kitzman DW (2011) Chronotropic incompetence: causes, consequences, and management. Circulation 123(9):1010-1020. https://doi.org/10.1161/CIRCULATIO NAHA.110.940577

12. Ingelsson E, Larson MG, Vasan RS et al (2007) Heritability, linkage, and genetic associations of exercise treadmill test responses. Circulation 115:2917-2924. https://doi.org/10.1161/CIRCU LATIONAHA.106.683821

13. Nederend I, Schutte NM, Bartels M et al (2016) Heritability of heart rate recovery and vagal rebound after exercise. Eur J Appl Physiol 116:2167-2176. https://doi.org/10.1007/s0042 1-016-3459-y

14. Verweij N, van de Vegte YJ, van der Harst P (2018) Genetic study links components of the autonomous nervous system to heart-rate profile during exercise. Nat Commun 9:898. https:// doi.org/10.1038/s41467-018-03395-6

15. Ramírez J, van Duijvenboden S, Ntalla I et al (2018) Thirty loci identified for heart rate response to exercise and recovery implicate autonomic nervous system. Nat Commun 9:1947. https:// doi.org/10.1038/s41467-018-04148-1

16. Rice T, An P, Gagnon J et al (2002) Heritability of HR and BP response to exercise training in the HERITAGE Family Study. Med Sci Sports Exerc 34:972-979 
17. An P, Pérusse L, Rankinen $T$ et al (2003) Familial aggregation of exercise heart rate and blood pressure in response to 20 weeks of endurance training: the HERITAGE family study. Int J Sports Med 24:57-62. https://doi.org/10.1055/s-2003-37200

18. Visscher PM, Wray NR, Zhang Q et al (2017) 10 years of GWAS discovery: biology, function, and translation. Am J Hum Genet 101:5-22. https://doi.org/10.1016/j.ajhg.2017.06.005

19. Coote JH (2010) Recovery of heart rate following intense dynamic exercise. Exp Physiol 95:431-440. https://doi. org/10.1113/expphysiol.2009.047548

20. Saghiv M, Sagiv M (2017) Response of left ventricular volumes and ejection fraction during different modes of exercise in health and CAD patients. Int J Clin Cardiol Res 1:51-56

21. Montgomery HE, Marshall R, Hemingway H et al (1998) Human gene for physical performance. Nature 393:221-222. https://doi. org/10.1038/30374

22. Voroshin IN, Astratenkova IV (2008) Dependence of endurance performance on ACE gene polymorphism in athletes. Hum Physiol 34:117-119. https://doi.org/10.1007/s10747-008-1018-6

23. Roltsch MH, Brown MD, Hand BD et al (2005) No association between ACE I/D polymorphism and cardiovascular hemodynamics during exercise in young women. Int J Sports Med 26:638-644. https://doi.org/10.1055/s-2004-830436

24. McCole SD, Brown MD, Moore GE et al (2002) Angiotensinogen M235T polymorphism associates with exercise hemodynamics in postmenopausal women. Physiol Genomics 10:63-69. https ://doi.org/10.1152/physiolgenomics.00106.2001

25. Rankinen T, Pérusse L, Gagnon J et al (2000) Angiotensin-converting enzyme ID polymorphism and fitness phenotype in the HERITAGE Family Study. J Appl Physiol 88:1029-1035. https ://doi.org/10.1152/jappl.2000.88.3.1029

26. Hand BD, McCole SD, Brown MD et al (2006) NOS3 gene polymorphisms and exercise hemodynamics in postmenopausal women. Int J Sports Med 27:951-958. https://doi. org/10.1055/s-2006-923901

27. Zanzinger J (1999) Role of nitric oxide in the neural control of cardiovascular function. Cardiovasc Res 43:639-649. https://doi. org/10.1016/s0008-6363(99)00085-1

28. Nieminen T, Lehtimäki T, Laiho J et al (2006) Effects of polymorphisms in beta1-adrenoceptor and alpha-subunit of $\mathrm{G}$ protein on heart rate and blood pressure during exercise test. The Finnish Cardiovascular Study. J Appl Physiol 100:507-511. https://doi. org/10.1152/japplphysiol.00899.2005

29. Defoor J, Martens K, Zielińska D et al (2006) The CAREGENE study: polymorphisms of the $\beta 1$-adrenoceptor gene and aerobic power in coronary artery disease. Eur Heart J 27:808-816. https ://doi.org/10.1093/eurheartj/ehi737

30. Eisenach JH, McGuire AM, Schwingler RM et al (2004) The $\operatorname{Arg} 16 /$ Gly $\beta 2$-adrenergic receptor polymorphism is associated with altered cardiovascular responses to isometric exercise. Physiol Genomics 16:323-328. https://doi.org/10.1152/physi olgenomics.00152.2003

31. Altmüller J, Palmer LJ, Fischer G et al (2001) Genomewide scans of complex human diseases: true linkage is hard to find. Am J Hum Genet 69:936-950. https://doi.org/10.1086/324069

32. Hirschhorn JN, Daly MJ (2005) Genome-wide association studies for common diseases and complex traits. Nat Rev Genet 6:95108. https://doi.org/10.1038/nrg1521

33. Hirschhorn JN (2005) Genetic approaches to studying common diseases and complex traits. Pediatr Res 57:74R-77R. https://doi. org/10.1203/01.PDR.0000159574.98964.87

34. Vasan RS, Larson MG, Aragam J et al (2007) Genome-wide association of echocardiographic dimensions, brachial artery endothelial function and treadmill exercise responses in the Framingham Heart Study. BMC Med Genet 8:S2. https://doi. org/10.1186/1471-2350-8-S1-S2
35. Tiso N, Stephan DA, Nava A et al (2001) Identification of mutations in the cardiac ryanodine receptor gene in families affected with arrhythmogenic right ventricular cardiomyopathy type 2 (ARVD2). Hum Mol Genet 10:189-194

36. Tsio N, Salamon M, Bagattin A et al (2002) The binding of the RyR2 calcium channel to its gating protein FKBP12.6 is oppositely affected by ARVD2 and VTSIP mutations. Biochem Biophys Res Commun 299:594-598. https://doi.org/10.1016/ S0006-291X(02)02689-X

37. Priori SG, Napolitano C, Memmi M et al (2002) Clinical and molecular characterization of patients with catecholaminergic polymorphic ventricular tachycardia. Circulation 106:69-74

38. Huffman JE (2018) Examining the current standards for genetic discovery and replication in the era of mega-biobanks. Nat Commun 9:5054. https://doi.org/10.1038/s41467-018-07348-x

39. Nuber S, Franck T, Wolburg H et al (2010) Transgenic overexpression of the alpha-synuclein interacting protein synphilin-1 leads to behavioral and neuropathological alterations in mice. Neurogenetics 11:107-120. https://doi.org/10.1007/s1004 8-009-0212-2

40. Smith WW, Liu Z, Liang Y et al (2010) Synphilin-1 attenuates neuronal degeneration in the A53T -synuclein transgenic mouse model. Hum Mol Genet 19:2087-2098. https://doi. org $/ 10.1093 / \mathrm{hmg} / \mathrm{ddq} 086$

41. Jarrous N, Eder PS, Wesolowski D, Altman S (1999) Rpp14 and Rpp29, two protein subunits of human ribonuclease $P$. RNA 5:153-157

42. Abu-Zhayia ER, Khoury-Haddad H, Guttmann-Raviv N et al (2017) A role of human RNase P subunits, Rpp29 and Rpp21, in homology directed-repair of double-strand breaks. Sci Rep 7:1002. https://doi.org/10.1038/s41598-017-01185-6

43. Raven PB, Chapleau MW (2014) Blood pressure regulation XI: overview and future research directions. Eur J Appl Physiol 114:579-586. https://doi.org/10.1007/s00421-014-2823-z

44. Fukuda T, Sugita S, Inatome R, Yanagi S (2010) CAMDI, a novel disrupted in schizophrenia 1 (DISC1)-binding protein, is required for radial migration. J Biol Chem 285:40554-40561. https://doi.org/10.1074/jbc.M110.179481

45. Brandon NJ, Sawa A (2011) Linking neurodevelopmental and synaptic theories of mental illness through DISC1. Nat Rev Neurosci 12:707-722. https://doi.org/10.1038/nrn3120

46. De Pontual L, Mathieu Y, Golzio C et al (2009) Mutational, functional, and expression studies of the TCF4 gene in pitthopkins syndrome. Hum Mutat 30:669-676. https://doi. org/10.1002/humu.20935

47. Sepp M, Pruunsild P, Timmusk T (2012) Pitt-Hopkins syndrome-associated mutations in TCF4 lead to variable impairment of the transcription factor function ranging from hypomorphic to dominant-negative effects. Hum Mol Genet 21:2873-2888. https://doi.org/10.1093/hmg/dds112

48. Tellier A-L, Amiel J, Delezoide A-L et al (2000) Expression of thePAX2 gene in human embryos and exclusion in the CHARGE syndrome. Am J Med Genet 93:85-88. https://doi. org/10.1002/1096-8628(20000717)93:2\%3c85:AID-AJMG1 \%3e3.0.CO;2-B

49. Lai T, Jabaudon D, Molyneaux BJ et al (2008) SOX5 controls the sequential generation of distinct corticofugal neuron subtypes. Neuron 57:232-247. https://doi.org/10.1016/J.NEURO N.2007.12.023

50. Lamb AN, Rosenfeld JA, Neill NJ et al (2012) Haploinsufficiency of SOX5 at 12p12.1 is associated with developmental delays with prominent language delay, behavior problems, and mild dysmorphic features. Hum Mutat 33:728-740. https://doi. org/10.1002/humu.22037

51. Galbiati F, Volonte D, Gil O et al (1998) Expression of caveolin-1 and -2 in differentiating PC12 cells and dorsal root 
ganglion neurons: caveolin-2 is up-regulated in response to cell injury. Proc Natl Acad Sci USA 95:10257-10262

52. Woitecki AMH, Müller JA, van Loo KMJ et al (2016) Identification of synaptotagmin 10 as effector of NPAS4mediated protection from excitotoxic neurodegeneration. J Neurosci 36:2561-2570. https://doi.org/10.1523/JNEUR OSCI.2027-15.2016

53. Kong Q, Zeng W, Wu J et al (2010) RNF220, an E3 ubiquitin ligase that targets Sin3B for ubiquitination. Biochem Biophys Res Commun 393:708-713. https://doi.org/10.1016/j. bbrc.2010.02.066

54. Ma P, Yang X, Kong Q et al (2014) The ubiquitin ligase RNF220 enhances canonical Wnt signaling through USP7-mediated deubiquitination of $\beta$-catenin. Mol Cell Biol 34:4355-4366. https:// doi.org/10.1128/MCB.00731-14

55. Facer P, Punjabi PP, Abrari A et al (2011) Localisation of SCN10A gene product Nav1.8 and novel pain-related ion channels in human heart. Int Heart J 52:146-152. https://doi. org/10.1536/ihj.52.146

56. Yang J, Huang J, Maity B et al (2010) RGS6, a modulator of parasympathetic activation in heart. Circ Res 107:1345-1349. https://doi.org/10.1161/CIRCRESAHA.110.224220

57. Wydeven N, Posokhova E, Xia Z et al (2014) RGS6, but not RGS4, is the dominant regulator of G protein signaling (RGS) modulator of the parasympathetic regulation of mouse heart rate. J Biol Chem 289:2440-2449. https://doi.org/10.1074/jbc. M113.520742

58. Bower M, Salomon R, Allanson J et al (2012) Update of PAX2 mutations in renal coloboma syndrome and establishment of a locus-specific database. Hum Mutat 33:457-466. https://doi. org/10.1002/humu.22020

59. Barua M, Stellacci E, Stella L et al (2014) Mutations in PAX2 associate with adult-onset FSGS. J Am Soc Nephrol 25:19421953. https://doi.org/10.1681/ASN.2013070686

60. Nolte IM, Munoz ML, Tragante V et al (2017) Genetic loci associated with heart rate variability and their effects on cardiac disease risk. Nat Commun 8:15805. https://doi.org/10.1038/ncomm s15805

61. Camm AJMM et al (1996) Heart rate variability: standards of measurement, physiological interpretation and clinical use. Task Force of the European Society of Cardiology and the North American Society of Pacing and Electrophysiology. Circulation 93:1043-1065

62. Ioannidis JPA, Ntzani EE, Trikalinos TA, Contopoulos-Ioannidis DG (2001) Replication validity of genetic association studies. Nat Genet 29:306-309. https://doi.org/10.1038/ng749

63. Morgan TM, Krumholz HM, Lifton RP, Spertus JA (2007) Nonvalidation of reported genetic risk factors for acute coronary syndrome in a large-scale replication study. JAMA 297:1551. https ://doi.org/10.1001/jama.297.14.1551

64. Imai K, Sato H, Hori M et al (1994) Vagally mediated heart rate recovery after exercise is accelerated in athletes but blunted in patients with chronic heart failure. J Am Coll Cardiol 24:15291535. https://doi.org/10.1016/0735-1097(94)90150-3

65. Kohli U, Diedrich A, Kannankeril PJ et al (2015) Genetic variation in alpha2-adrenoreceptors and heart rate recovery after exercise. Physiol Genomics 47:400-406. https://doi.org/10.1152/ physiolgenomics.00124.2014

66. Hautala AJ (2006) Heart rate recovery after maximal exercise is associated with acetylcholine receptor M2 (CHRM2) gene polymorphism. AJP Hear Circ Physiol 291:H459-H466. https://doi. org/10.1152/ajpheart.01193.2005

67. Hautala AJ, Tulppo MP, Kiviniemi AM et al (2009) Acetylcholine receptor M2 gene variants, heart rate recovery, and risk of cardiac death after an acute myocardial infarction. Ann Med 41:197-207. https://doi.org/10.1080/07853890802477866
68. Brodde OE, Michel MC (1999) Adrenergic and muscarinic receptors in the human heart. Pharmacol Rev 51:651-690

69. Whittaker VP (1990) The contribution of drugs and toxins to understanding of cholinergic function. Trends Pharmacol Sci 11:8-13. https://doi.org/10.1016/0165-6147(90)90034-6

70. Nikolaienko RM, Hammel M, Dubreuil V et al (2016) Structural basis for interactions between contactin family members and protein-tyrosine phosphatase receptor type $\mathrm{G}$ in neural tissues. J Biol Chem 291:21335-21349. https://doi.org/10.1074/ jbc.M116.742163

71. Walsh CA, Morrow EM, Rubenstein JLR (2008) Autism and brain development. Cell 135:396-400. https://doi. org/10.1016/J.CELL.2008.10.015

72. Connelly MA, Grady RC, Mushinski JF, Marcu KB (1994) PANG, a gene encoding a neuronal glycoprotein, is ectopically activated by intracisternal A-type particle long terminal repeats in murine plasmacytomas. Proc Natl Acad Sci USA 91:1337-1341

73. Ruffle JK, Coen SJ, Giampietro V et al (2018) Morphology of subcortical brain nuclei is associated with autonomic function in healthy humans. Hum Brain Mapp 39:381-392. https://doi. org $/ 10.1002 / \mathrm{hbm} .23850$

74. Pfeffer PL, Payer B, Reim G et al (2002) The activation and maintenance of Pax 2 expression at the mid-hindbrain boundary is controlled by separate enhancers. Development 129:307-318

75. Kapa S, DeSimone CV, Asirvatham SJ (2016) Innervation of the heart: an invisible grid within a black box. Trends Cardiovasc Med 26:245-257. https://doi.org/10.1016/j. tcm.2015.07.001

76. Utami KH, Winata CL, Hillmer AM et al (2014) Impaired development of neural-crest cell-derived organs and intellectual disability caused by MED13L haploinsufficiency. Hum Mutat 35:1311-1320. https://doi.org/10.1002/humu.22636

77. Asadollahi R, Zweier M, Gogoll L et al (2017) Genotype-phenotype evaluation of MED13L defects in the light of a novel truncating and a recurrent missense mutation. Eur J Med Genet 60:451-464. https://doi.org/10.1016/j.ejmg.2017.06.004

78. Piven OO, Winata CL (2017) The canonical way to make a heart: $\beta$-catenin and plakoglobin in heart development and remodeling. Exp Biol Med 242:1735-1745. https://doi.org/10.1177/15353 70217732737

79. Nakagawa A, Naito AT, Sumida T et al (2016) Activation of endothelial $\beta$-catenin signaling induces heart failure. Sci Rep 6:25009. https://doi.org/10.1038/srep25009

80. Pahnke A, Conant G, Huyer LD et al (2016) The role of Wnt regulation in heart development, cardiac repair and disease: a tissue engineering perspective. Biochem Biophys Res Commun 473:698-703. https://doi.org/10.1016/j.bbrc.2015.11.060

81. Foulquier S, Daskalopoulos EP, Lluri G et al (2018) WNT signaling in cardiac and vascular disease. Pharmacol Rev 70:68-141. https://doi.org/10.1124/pr.117.013896

82. Berger I, Hershkovitz E, Shaag A et al (2008) Mitochondrial complex I deficiency caused by a deleterious NDUFA11 mutation. Ann Neurol 63:405-408. https://doi.org/10.1002/ana.21332

83. Jang S, Javadov S (2018) Elucidating the contribution of ETC complexes I and II to the respirasome formation in cardiac mitochondria. Sci Rep 8:17732. https://doi.org/10.1038/s41598-01836040-9

84. Wiegreffe C, Simon R, Peschkes K et al (2015) Bcl11a (Ctip1) controls migration of cortical projection neurons through regulation of Sema3c. Neuron 87:311-325. https://doi.org/10.1016/j. neuron.2015.06.023

85. Dias C, Estruch SB, Graham SA et al (2016) BCL11A haploinsufficiency causes an intellectual disability syndrome and dysregulates transcription. Am J Hum Genet 99:253-274. https:// doi.org/10.1016/j.ajhg.2016.05.030 
86. Saiki Y, Yamazaki Y, Yoshida M et al (2000) Human EVI9, a homologue of the mouse myeloid leukemia gene, is expressed in the hematopoietic progenitors and down-regulated during myeloid differentiation of HL60 cells. Genomics 70:387-391. https://doi.org/10.1006/geno.2000.6385

87. Koskela J, Laiho J, Kähönen M et al (2008) Potassium channel KCNH2 K897T polymorphism and cardiac repolarization during exercise test: the Finnish Cardiovascular study. Scand J Clin Lab Invest 68:31-38. https://doi.org/10.1080/00365510701496488

88. Dai G, Zagotta WN (2017) Molecular mechanism of voltagedependent potentiation of KCNH potassium channels. Elife 6:e26355. https://doi.org/10.7554/eLife.26355

89. Li X, Martinson AS, Layden MJ et al (2015) Ether-à-go-go family voltage-gated $\mathrm{K}+$ channels evolved in an ancestral metazoan and functionally diversified in a cnidarian-bilaterian ancestor. $\mathrm{J}$ Exp Biol 218:526-536. https://doi.org/10.1242/jeb.110080

90. Kupershmidt S, Yang IC-H, Hayashi K et al (2003) The IKr drug response is modulated by KCR1 in transfected cardiac and noncardiac cell lines. FASEB J 17:2263-2265. https://doi. org/10.1096/fj.02-1057fje

91. Gilman AG (1987) G Proteins: transducers of receptor-generated signals. Annu Rev Biochem 56:615-649. https://doi.org/10.1146/ annurev.bi.56.070187.003151

92. Petersen CI, McFarland TR, Stepanovic SZ et al (2004) In vivo identification of genes that modify ether-a-go-go-related gene activity in Caenorhabditis elegans may also affect human cardiac arrhythmia. Proc Natl Acad Sci 101:11773-11778. https://doi. org/10.1073/pnas.0306005101

93. Contractor A, Mulle C, Swanson GT (2011) Kainate receptors coming of age: milestones of two decades of research. Trends Neurosci 34:154-163. https://doi.org/10.1016/J. TINS.2010.12.002

94. Pischedda F, Szczurkowska J, Cirnaru MD et al (2014) A cell surface biotinylation assay to reveal membrane-associated neuronal cues: Negr1 regulates dendritic arborization. Mol Cell Proteomics 13:733-748. https://doi.org/10.1074/mcp.M113.031716

95. Wilmore JH, Stanforth PR, Gagnon J et al (2001) Heart rate and blood pressure changes with endurance training: the HERITAGE family study. Med Sci Sports Exerc 33:107-116

96. Rankinen T, Argyropoulos G, Rice T et al (2010) CREB1 is a strong genetic predictor of the variation in exercise heart rate response to regular exercise: the HERITAGE family study. Circ Cardiovasc Genet 3:294-299. https://doi.org/10.1161/CIRCG ENETICS.109.925644

97. Rankinen T, Sung YJ, Sarzynski MA et al (2012) Heritability of submaximal exercise heart rate response to exercise training is accounted for by nine SNPs. J Appl Physiol 112:892-897. https ://doi.org/10.1152/japplphysiol.01287.2011

98. Malaspina A, Kaushik N, de Belleroche J (2000) A 14-3-3 mRNA is up-regulated in amyotrophic lateral sclerosis spinal cord. J Neurochem 75:2511-2520

99. Lau JMC, Jin X, Ren J et al (2007) The 14-3-3tau phosphoserinebinding protein is required for cardiomyocyte survival. Mol Cell Biol 27:1455-1466. https://doi.org/10.1128/MCB.01369-06

100. Patberg KW, Shvilkin A, Plotnikov AN et al (2005) Cardiac memory: mechanisms and clinical implications. Hear Rhythm 2:1376-1382. https://doi.org/10.1016/j.hrthm.2005.08.021

101. Wu H, Zhou Y, Xiong Z-Q (2007) Transducer of regulated CREB and late phase long-term synaptic potentiation. FEBS J 274:3218-3223. https://doi.org/10.1111/j.1742-4658.2007.05891 .
102. Pickering C, Kiely J (2017) Exercise genetics: seeking clarity from noise. BMJ Open Sport Exerc Med 3:e000309. https://doi. org/10.1136/bmjsem-2017-000309

103. Karoly HC, Stevens CJ, Magnan RE et al (2012) Genetic influences on physiological and subjective responses to an aerobic exercise session among sedentary adults. J Cancer Epidemiol 2012:1-12. https://doi.org/10.1155/2012/540563

104. Wangler MF, Hu Y, Shulman JM (2017) Drosophila and genomewide association studies: a review and resource for the functional dissection of human complex traits. Dis Model Mech 10:77-88. https://doi.org/10.1242/dmm.027680

105. Hamel V, Cheng K, Liao S et al (2017) De Novo human cardiac myocytes for medical research: promises and challenges. Stem Cells Int 2017:1-7. https://doi.org/10.1155/2017/4528941

106. Chen IY, Matsa E, Wu JC (2016) Induced pluripotent stem cells: at the heart of cardiovascular precision medicine. Nat Rev Cardiol 13:333-349. https://doi.org/10.1038/nrcardio.2016.36

107. Smith SC, Benjamin EJ, Bonow RO et al (2011) AHA/ACCF secondary prevention and risk reduction therapy for patients with coronary and other atherosclerotic vascular disease: 2011 update. J Am Coll Cardiol. https://doi.org/10.1161/CIR.0b013 e318235eb4d

108. Ponikowski P, Voors AA, Anker SD et al (2016) 2016 ESC guidelines for the diagnosis and treatment of acute and chronic heart failure. Eur Heart J 37:2129-2200. https://doi.org/10.1093/ eurheartj/ehw128

109. Swedberg K, Komajda M, Böhm M et al (2010) Ivabradine and outcomes in chronic heart failure (SHIFT): a randomised placebo-controlled study. Lancet 376:875-885. https://doi. org/10.1016/S0140-6736(10)61198-1

110. Kumamaru H, Kadoya K, Adler AF et al (2018) Generation and post-injury integration of human spinal cord neural stem cells. Nat Methods 15:723-731. https://doi.org/10.1038/s4159 2-018-0074-3

111. Mouse Genome Sequencing Consortium, Waterston RH, Lindblad-Toh $\mathrm{K}$ et al (2002) Initial sequencing and comparative analysis of the mouse genome. Nature 420:520-562. https://doi. org/10.1038/nature01262

112. van der Harst $P$, van Setten J, Verweij $N$ et al (2016) 52 genetic loci influencing myocardial mass. J Am Coll Cardiol 68:14351448. https://doi.org/10.1016/j.jacc.2016.07.729

113. Bier E (2005) Drosophila, the golden bug, emerges as a tool for human genetics. Nat Rev Genet 6:9-23. https://doi.org/10.1038/ $\operatorname{nrg} 1503$

114. Howe K, Clark MD, Torroja CF et al (2013) The zebrafish reference genome sequence and its relationship to the human genome. Nature 496:498-503. https://doi.org/10.1038/nature12111

115. Khera AV, Chaffin M, Aragam KG et al (2018) Genome-wide polygenic scores for common diseases identify individuals with risk equivalent to monogenic mutations. Nat Genet 50:12191224. https://doi.org/10.1038/s41588-018-0183-z

116. Said MA, Verweij N, van der Harst P (2018) Associations of combined genetic and lifestyle risks with incident cardiovascular disease and diabetes in the UK biobank study. JAMA Cardiol 3:693. https://doi.org/10.1001/jamacardio.2018.1717

117. Kraft P, Zeggini E, Ioannidis JPA (2009) Replication in genomewide association studies. Stat Sci 1:1. https://doi.org/10.1214/09STS290

Publisher's Note Springer Nature remains neutral with regard to jurisdictional claims in published maps and institutional affiliations. 